\title{
INSTRUMENTAL MUSIC AND 'CONVERSAZIONE' IN EARLY SEICENTO VENICE: BIAGIO MARINI’S ‘AFFETTI MUSICALI' (1617)
}

\author{
By ReBecca CyPess*
}

ON 26 June 1612 Galileo Galilei answered a request from a friend, the artist Lodovico Cardi da Cigoli, for his opinion on the age-old debate over the relative merits of painting and sculpture. He responded that, because sculpture is three-dimensional and therefore closer to nature, he deemed painting the more praiseworthy of the two arts. Since we know that he came from a musical family, it is perhaps not surprising that in offering his judgement Galileo made reference to music:

There is an imperfection, and a thing that greatly decreases the praise due to sculpture: for the farther the medium of imitation is from the things being imitated, that much more is the imitation marvellous.... Would we not admire a musician, who, through singing, represents the feelings and passions of a lover, and moves us to have compassion for him, much more than if he were to do so through weeping? And this is because singing is a means not only different from, but contrary to the expression of sadness, and tears and plaints are very similar to it. And would we not admire [the musician] much more if he did so without voice, with the instrument alone, with musical dissonances and pathos-filled sounds, since the inanimate strings are less able to awaken the secret affetti of our soul, than the voice is in telling of them? For this reason, therefore, what marvel would there be in imitating Nature, the Sculptress, with sculpture itself, and representing a relief with the same relief? ... Thus painting is more marvellous than sculpture. ${ }^{1}$

\footnotetext{
*Mason Gross School of the Arts, Rutgers, The State University of New Jersey. Email: rebecca.cypess@ gmail.com. The author wishes to thank Rebecca Herissone, Eric Bianchi, Bonnie Blackburn, and Andrew Dell'Antonio for their valuable advice concerning this essay.

1 'È a loro imperfezione, e cosa che scema grandissimamente il pregio alla scultura: perciocché quanto più i mezzi, co' quali si imita, son lontani dalle cose da imitarsi, tanto più l'imitazione è maravigliosa.... Non ammireremmo noi un musico, il quale cantando e rappresentandoci le querele e le passioni d'un amante ci muovesse a compassionarlo, molto più che se piangendo ciò facesse? e questo, per essere il canto un mezzo non solo diverso, ma contrario ad esprimere i dolori, e le lagrime et il pianto similissimo. E molto più l'ammireremmo, se tacendo, col solo strumento, con crudezze et accenti patetici musicali, ciò facesse, per esser le inanimate corde meno atte a risvegliare gli affetti occulti dell'anima nostra, che la voce raccontandole. Per questa ragione dunque, di qual maraviglia sarà l'imitare la natura scultrice coll'istessa scultura, e rappresentare il rilevato coll'istesso rilevo? ... Maravigliosa dunque, per tal rispetto, si rende più la pittura che la scultura.' Galileo Galilei to Lodovico Cigoli, dated 26 June 1612. Transcribed in Le opere di Galileo Galilei, xi, ed. Antonio Favaro (Florence, 1901), 340-3 and in Scritti d'arte del Cinquecento, i, ed. Paola Barocchi (Milan, 1971), 707-11. Translations are mine unless otherwise noted. Emphasis mine.

The authenticity of this letter has been a subject of debate for over a century, having first been called into question by Favaro in a note preceding his transcription of it (Le opere di Galileo Galilei, xi. 340). However, Horst Bredekamp presents a compelling case for its authenticity, arguing that Galileo's letter constituted a carefully formulated defence of his methods of drawing the unsmooth lunar surface, which he had observed through his telescope and publicized for the first time only two years earlier in his Sidereus Nuncius (Venice, 1610). It was this controversial feature of Galileo's observations that Cigoli had rendered in one of his paintings in the Pauline Chapel, and thus Galileo's addressing of the letter to Cigoli was, as Bredekamp writes, 'more than just a friendly duty'. See Horst Bredekamp, Galilei der Künstler: Der Mond. Die Sonne. Die Hand (Berlin, 2007), 283-8. The most recent essay to suggest that the letter is not by Galileo is Maurice A. Finocchiaro, 'Galilean Argumentation and the Inauthenticity of the
} 
For Galileo, then, both painting and instrumental music inspire a sense of meraviglia by employing artifice to 'awaken the secret affetti of our soul'. It is the medium of the imitation - the brush and pigments of the painter, the wood and gut that make up the musician's instrument - that dictates the imitation's effectiveness. The farther it is from the natural phenomenon, the more it inspires the sense of wonder so integral to the early modern aesthetic experience. ${ }^{2}$

It is worth noting at the outset that Galileo's statement calls into question, or at least complicates, the commonly held view that in the early seventeenth century the boldest innovations occurred in the domain of vocal music, and that instrumental music merely followed suit. ${ }^{3}$ Although it has long been recognized that this period witnessed the first rise of extended, idiomatic solo instrumental music in the Western tradition - a repertory intended to be listened to, and in which the virtuoso assumed centre stage - the motivating forces behind this revolution in instrumental composition have never been fully understood. Galileo's letter to Cigoli goes a long way towards explaining this phenomenon: according to his account, the emergence of this new instrumental repertory may be seen as a manifestation of the early modern interest in instruments in general-scientific and artistic tools that helped to mediate between the individual and his social and natural environments.

The relationship between instrumental music and instrumentality is complex; ${ }^{4}$ in this essay, I address the topic in a preliminary way by considering some of the cultural forces that might have helped to foster the experimentation and innovation necessary for the development of this new repertory. Given Galileo's emphasis on the affetti of listeners, it seems natural to begin by assessing the earliest publication to apply that suggestive term to the title of a collection of instrumental music: Biagio Marini's Affetti musicali. ${ }^{5}$ This volume - the composer's first publication - has been

Cigoli Letter on Painting vs. Sculpture', Studies in History and Philosophy of Science, 42 (2011), 492-508; Finocchiaro's argument is philological in nature, and it does not fully address Bredekamp's 2007 interpretation. For two other works that treat the letter as authentic, see Erwin Panofsky, Galileo as a Critic of the Arts (The Hague, 1954), 4-10, and Steven F. Ostrow, 'Playing with the Paragone: The Reliefs of Pietro Bernini', Zeitschrift für Kunstgeschichte, 67 (2004), 329-64. I am grateful to Mario Biagioli, Robert Holzer, and Eileen Reeves for their advice on this issue.

${ }^{2}$ Bonnie Gordon has considered the use of instruments in Claudio Monteverdi's Orfeo as a manifestation of the early 17 th-c. preoccupation with machinery and natural magic, but this idea has not previously been applied to the new instrumental repertory itself. Furthermore, I suggest that Galileo's conception of instrumentality represents a departure from the views of magic in music that dominated Renaissance thought. See Bonnie Gordon, 'Orfeo's Machines', Opera Quarterly, 24 (2008), 200-22. Gordon and Gary Tomlinson both note the Neoplatonic and Ficinian impulses behind the use of musical instruments to inspire certain reactions in listeners; see Gary Tomlinson, Music in Renaissance Magic: Toward a Historiography of Others (Chicago and London, 1993).

${ }^{3}$ For a recent expression of this view, see Timothy A. Collins, 'Musica secreta strumentali: The Aesthetics and Practice of Private Solo Instrumental Performance in the Age of Monody (Ca. 1580-Ca. 1610)', International Review of the Aesthetics and Sociology of Music, 35 (2004), 47-62 at 60-1. Andrew Dell'Antonio, however, has suggested that this assumption is based on an overly credulous reading of the theoretical literature of the early Seicento. Although composers and theorists justified their stylistic innovations by claiming that the new music responded to the needs of the text, this justification may have been a rhetorical conceit formulated after the fact, rather than an a priori intention of the composers as they sat down to write. As Dell'Antonio explains, 'While it is easy for us to accept contemporary writers' neglect of instrumental music as a sign that such music was not held in high esteem, it is also crucial to analyze the musical roots of the seconda prattica, to understand how the theories relate to actual compositional praxis.' Andrew Dell'Antonio, Syntax, Form and Genre in Sonatas and Canzonas, 1621-1635 (Quaderni di Musica/Realtà, 38; Lucca, 1997), $281-305$ at 293.

${ }^{4}$ It is this interaction that forms the basis of my book, now in progress, provisionally entitled 'Curious and Modern Inventions': Humanism and the Mechanics of Italian Instrumental Music, 1610-1630.

${ }^{5}$ Biagio Marini, Affetti musicali... nella quale si contiene, symfonie, canzon, sonate balletti, arie, brandi, gagliarde Ë corenti à

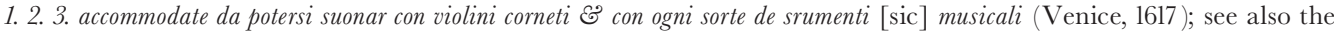
facs. edn., id. Affetti musicali: Venezia 1617 (Archivum musicum/Collana di testi rari, 7; Florence, 1985); and also the modern edition, id. Affetti musicali: Opera prima, ed. and with an introduction by Franco Piperno (Opere di antiche 
noted in the scholarly literature for its pioneering use of violin tremolo and other novelties. ${ }^{6}$ More generally, many writers have cited the volume's status as one of the earliest publications of instrumental music devoted to the stile moderno, since it utilizes the polarized soprano-bass texture so common in vocal music of the early Seicento, and often embraces an aesthetic of fragmentation and capriciousness, with quickly changing motifs and harmonies. ${ }^{7}$ As Table 1 demonstrates, the volume contains a wide array of genres and suggestions for instrumentation, which led some earlier writers to express discomfort at its seeming lack of organization. ${ }^{8}$ However, Franco Piperno has advanced the theory that the variety inherent in the collection- not only in its musical material, but in its construction as well - was, in fact, an essential feature of the instrumental stile moderno: 'In reality', he states, 'if an organizing principle of the Affetti musicali does exist, it lies, paradoxically, in the apparent disorder of the collection." 9

Through his title, Marini seems to make special claims for the capacity of untexted music, as Piperno writes, 'to entertain, to communicate, to move, to stupefy, to entice'. ${ }^{10}$ Beyond this notion of a general stirring of the emotions, however, there may be additional layers of meaning inscribed in Marini's Affetti musicali. Addressing his patrons, Marini recalls that his music had already been performed 'né giuditiosi concerti delle loro recreationi' (in judicious concerti of your recreations). ${ }^{11}$ Thus at least some of his compositions were written for actual performance at the social musical gatherings of a progressive group of Venetian listeners - perhaps something like an informal academy. Whereas previous literature has considered this volume as a bookas a printed object, fixed and permanent - I suggest an alternative interpretation, rooted in the notion of the printed text as a product of the live music-making to which Marini refers.

In this essay I attempt to gain a new perspective on Marini's collection by contextualizing it within contemporaneous theories of civility and friendship. In particular, I call upon two literary works. The first is Stefano Guazzo's Civil conversazione, a treatise on sociability and friendship that was highly influential across Italyindeed, throughout much of Europe - from the time of its first publication in 1574.

musicisti bresciani, 5; Monumenti musicali italiani, 15; Milan, 1990). Marini signed the dedication of the volume 'di Venetia alli 25. Genaro M DC XVII'; given the fact that in the Venetian calendar in this period the year changed on 1 Mar., Piperno suggests that the date of publication was actually Jan. 1618 in modern terms, although this cannot be proven definitively.

${ }^{6}$ See Stewart Carter, 'The String Tremolo in the Seventeenth Century', Early Music, 19 (1991), 42-59, and also Eleanor Selfridge-Field, Venetian Instrumental Music from Gabrieli to Vivaldi (3rd edn., New York and London, 1994), $127-32$.

${ }^{7}$ On the stile moderno, see Dell'Antonio, Syntax, Form, and Genre; Rebecca Cypess, "Esprimere la voce humana": Connections between Vocal and Instrumental Music by Italian Composers of the Early Seventeenth Century', Fournal of Musicology, 27 (2010), 181-223; and Franco Piperno, "Concerto" e "concertato" nella musica strumentale italiana del secolo decimosettimo', Recercare, 3 (1991), 169-202. Analyses of Marini's sonatas, including those in the Affetti musicali, appear in Thomas D. Dunn, 'The Sonatas of Biagio Marini: Structure and Style', Music Review, 36 (1975), 161-79.

${ }^{8}$ See e.g. Willi Apel, Italian Violin Music of the Seventeenth Century, ed. Thomas Binkley (Bloomington, 1990), 47-8. Thomas D. Dunn attributes the ordering of the pieces in the book to the publisher; see 'The Instrumental Music of Biagio Marini', 2 vols. (Ph.D. thesis, Yale University, 1969), i. 12-13.

9 Marini, Affetti musicali, ed. Piperno, p. xxxi.

10 'la capacità di intrattenere, comunicare, commuovere, stupire, sedurre'; ibid. p. xxix.

11 The term concerto is not easy to translate. The modern word 'concert' has the connotation of a frontal performance, in which the players monopolize the spotlight, and the listeners are passive recipients of the music. In the 17 th c., concerto indicated a coordination of musical sounds, but it may also have served as a metaphor for the conversation and coordination of friends. This topic is discussed further below. 
TABLE 1. Contents of Marini's Affetti musicali

Scoring (such as 'A2' or 'A Un Violino Solo') and suggested instrumentation are taken from the Tavola of the canto primo partbook. The ratios in parentheses indicate the number of independent parts used in each composition (e.g. 2/1 indicates two soprano parts and one bass part independent of the basso continuo). The figure 0 indicates that there is no separate part for a bass-register instrument. No. 14, 'La Hiacintina', is actually by Marini's uncle, Hiacinto Bondioli.

\begin{tabular}{|c|c|c|c|c|}
\hline No. & Title & Genre & Texture & Instrumentation \\
\hline 1 & Il Zontino & Balletto & A3 (2/1) & Doi violini è Basso \\
\hline 2 & Il Vendramino & Balletto overo synfonia & A3 $(2 / 1)$ & Doi violini ò cornetto è basso \\
\hline 3 & Il Monteverde & Balletto alemano & $\mathrm{A} 2(2 / 0)$ & Violino è basso \\
\hline 4 & La Albana & Symfonia breve & $\mathrm{A} 2(2 / 0)$ & Violini ò cornetti \\
\hline 5 & La Candela & Symfonia breve & A2 $(2 / 0)$ & Violini ò cornetti \\
\hline 6 & La Zorzi & Symfonia grave & A3 $(2 / 1)$ & Doi violini è basso \\
\hline 7 & La Cornera & Symfonia & $\mathrm{A} 2(2 / 0)$ & Doi violini ò cornetti \\
\hline 8 & La Boccha & Symfonia allegra & A3 $(2 / 1)$ & Doi violini è basso \\
\hline 9 & La Martinenga & Symfonia & $\mathrm{A} 2(2 / 0)$ & Violini ò cornetti \\
\hline 10 & La Ponte & Sonata & $\mathrm{A} 2(1 / 1)$ & Violino ò corneto è basso \\
\hline 11 & La Giustiniana & Symfonia & A3 $(2 / 1)$ & $\begin{array}{l}\text { Doi violini ò corneti è } \\
\text { trombone }\end{array}$ \\
\hline 12 & La Bemba & Canzon & A2 $(2 / 0)$ & Violini ò cornetti \\
\hline 13 & La Foscarina & Sonata & A3 $(2 / 1)$ & $\begin{array}{l}\text { Doi violini ò corneti è } \\
\text { trombone ò fagotto }\end{array}$ \\
\hline 14 & La Hiacintina & Canzone & A2 $(1 / 1)$ & $\begin{array}{l}\text { Violino ò corneto è } \\
\text { trombone }\end{array}$ \\
\hline 15 & La Gambara & Symfonia & A3 (2/1) & $\begin{array}{l}\text { Doi violini è cornetti ò basso } \\
{[\mathrm{sic}]}\end{array}$ \\
\hline 16 & La Marina & Canzone & A3 $(1 / 2)$ & $\begin{array}{l}\text { Doi tromboni è corneto ò } \\
\text { violino }\end{array}$ \\
\hline 17 & La Zoppa & Symfonia allegra & A3 $(2 / 1)$ & Doi violini è basso \\
\hline 18 & La Orlandina & Symfonia & $\mathrm{A}$ un $\ldots(1 / 0)$ & $\begin{array}{l}\text { Violino ò corneto è basso se } \\
\text { piace }\end{array}$ \\
\hline 19 & La Gardana & Symfonia & A un $\ldots(1 / 0)$ & Violino ò corneto solo \\
\hline 20 & La Aguzzona & Sonata & A3 $(2 / 1)$ & Doi violini è fagotto \\
\hline 21 & La Soranza & Aria & A3 $(2 / 1)$ & Doi violini è basso \\
\hline 22 & La Boldiera & Aria & A3 $(2 / 1)$ & Doi violini è basso \\
\hline 23 & Il Barizone & Brando & A3 $(2 / 1)$ & Doi violini è basso \\
\hline 24 & Il Boncio & Brando & A2 $(1 / 1)$ & Violino è basso \\
\hline 25 & La Caotorta & Gagliarda & A Doi $(1 / 1)$ & Basso è violino \\
\hline 26 & La Martia & Corente & A3 $(2 / 1)$ & Doi violini \& basso \\
\hline 27 & La Vetrestain & Corente & A Doi $(1 / 1)$ & Violino è basso \\
\hline
\end{tabular}

Guazzo's work is a handbook for live social interactions like those at which Marini's instrumental works had their premieres. The second is a published volume of letters by the humanist cleric and poet Angelo Grillo, edited by another poet, Pietro Petracci, who, as I will show, was connected to Marini's musical publication. Grillo and Petracci seem to have been especially concerned with the preservation of the affetti of friendship through written letters, and with the modelling of stylized affetti through the publication of those letters. The writings of Guazzo, Grillo, and Petracci help to shed light on the concerti at which Marini's music was first performed. What 
emerges is an environment of experimentation and attentive listening, in which conversazione about music in the company necessary for friends served to stimulate the affetti of those who gathered to hear Marini's works.

\section{PERFORMING THE AFFETTI: INSTRUMENTAL MUSIC AND 'CIVIL CONVERSATION'}

On 25 January 1617, Marini, then employed as a violinist at St Mark's under the supervision of Claudio Monteverdi, signed the dedication of his Affetti musicali to the brothers Tommaso and Giovanni Maria Giunti, heirs to a prominent printing firm with branches in Venice, Florence, and abroad: ${ }^{12}$

I, to serve and obey several of my Lords and Patrons, who have insisted upon it heatedly, allow these, my musical compositions - or, to say it better, miscarriages of my efforts - to be published. And, because I suspect that they would no sooner be born than be relegated to eternal oblivion, either because of their failings, or because of the evil of these times, I rest them confidently on the patronage of your Most Illustrious Lordships, adorned by your name, certain that, since some of these already had the honour of being admitted to the home of your Most Illustrious Lordships in the judicious concerti of your recreations, the others may now also be heard; and they will go out [into the world] with proof of your approval, and thus not fear that they are altogether torn and spent, because of the universal esteem inspired by the singular cognition and extraordinary intelligence of your Most Illustrious Lordships, in music, and in every other virtuous deed. ${ }^{13}$

If the composer's references to the Giunti brothers' 'cognition', 'intelligence', and 'virtue' are common in such writings, his description of the musical performances themselves is more noteworthy: he refers to them as the judicious concerti hosted by the Giunti. To be sure, the term giudizioso was used with increasing frequency in referring to the tastes of cultural virtuosi in this period, ${ }^{14}$ but it takes on special significance with respect to the performance of instrumental music. Since it was difficult to coordinate instruments tastefully in an ensemble, and attempts to do so had sparked

\footnotetext{
${ }^{12}$ Documents concerning the activities of Tommaso and Giovanni Maria Giunti as printers are reproduced in Paolo Camerini, Annali dei Giunti, 2 vols. (Biblioteca bibliografica italica, 26, 28; Florence, 1962-3), i. 207-306. They indicate (ibid. 207) that Tommaso and Giovanni Maria lived, together with their mother Bianca [née Verdi or Verde], in the Palazzo di S. Eustachio on Venice's Canal grande, which had been acquired by their father, Lucantonio the Younger; the building is now known as the Palazzo Coccina Giunti Foscarini Giovanelli. An assessment of the Venetian branch of the Giunti family as patrons of art is given in Bert W. Meijer, 'New Light on Christoph Schwarz in Venice and the Veneto', Artibus et Historiae, 39 (20) (1999), 127-56. On the Giunti family in Venice see also William A. Pettas, A History and Bibliography of the Giunti ( Junta) Printing Family in Spain, 1514-1628 (New Castle, Del., 2005 ), 2-7; id., 'An International Renaissance Publishing Family: The Giunti', Library Quarterly, 44 (1974), 334-9; and Jane A. Bernstein, Print Culture and Music in Sixteenth-Century Venice (Oxford, 2001). On the work of the Giunti branch in Florence, see William A. Pettas, The Giunti of Florence: Merchant Publishers of the Sixteenth Century (San Francisco: B. M. Rosenthal, 1980); and Tim Carter, Music, Patronage and Printing in Late Renaissance Florence (Variorum Collected Studies Series, CS682; Aldershot, 2000).

${ }^{13}$ From Marini, Affetti musicali, Dedication: 'Io per servire, \& obedire ad alcuni miei Signori, e Padroni, che me né fanno caldissima instanza, lascio venire in Luce queste miei Musicali Compositioni, ò per meglio dire, aborti delle mie fatiche. E, perche dubito che non si tosto nate, sianno d'eterna oblivione, ò per manchezza loro, ò per malignità de questi tempi, adombrate, L'ho appogiate confidentemente al patrocinio del le Signorie V.V.M. Illustri, \& Ornate del nome loro; sicuro che, si come di già alcune d'esse hebbero l'honore d'essere sentite à suonarsi in Casa pure delle Signorie, VV.M. Illustri, se saranno tal'hora amesse, dopo l'altre, né giuditiosi Concerti delle loro recreationi, potranno poi co'l testimonio di si fatta probatione uscirsene, \& non temere d'essere in tutto lacerate, \& spente; per la stima universale che viene fatta dalla singolare cognitione, \& intelligenza piú che ordinaria delle Signorie VV.M. Illustri, nella Musica, \& in ogn'altra virtuosa attione.' Emphasis mine.

${ }^{14}$ See Andrew Dell'Antonio, Listening as Spiritual Practice in Early Modern Italy (Berkeley, 2011), 49-51, 95-120, and passim.
} 
ample criticism from theorists in the preceding decades, ${ }^{15}$ judiciousness can be interpreted here as a marker of understanding necessary for the management and harmonization of otherwise dissonant sounds. ${ }^{16}$

Although Marini's dedication seeks out special protection from the Giunti brothers, he also refers to several 'Lords and Patrons' who pressed him to publish his works, and indeed, the construction of the book points to the involvement of numerous other individuals or families in addition to the Giunti. Including the first piece, 'Il Zontino', ('Zonti' being a Venetian form of 'Giunti' ${ }^{17}$ ), the book contains twenty-seven works, all of which bear family-name titles. Many of these names were common in Venice and the surrounding area, so few pieces can be linked definitively with a particular individual. However, Piperno has compiled an extensive table of people bearing these names in Venice who may have belonged within the social circle of the Giunti and whom Marini may have had in mind when he allocated titles to his works in the Affetti musicali. ${ }^{18}$ They include patricians and cittadini, some individuals with connections to Venetian governance, composers, clerics, secretaries, jurists, military leaders, and academicians. Although a few of the names may refer to families from outside Venice, Marini's dedication suggests that a member of those families may have been present at the concerti in the Giunti home. As a whole, in what seems to be a distinctly Venetian amalgam reflecting the republican pretensions of the Serenissima, the Affetti musicali unites in print inhabitants of a wide array of social strata and occupations. 19 Most are not members of the uppermost ranks of the nobility; instead, as a group, they represent what Monika Schmitter has called a 'bricolage of identities' of cittadini and lesser Venetian nobility. ${ }^{20}$

Still, the precise function of these family-name titles in the Italian repertory of the late sixteenth and early seventeenth centuries has not yet been adequately explained. Eleanor Selfridge-Field refers to the works that bear such titles simply as 'dedicatory pieces'; ${ }^{21}$ Peter Allsop suggests that the titles served an essentially commercial purpose, encouraging purchase of the books containing them by a 'ready market of enthusiastic amateurs' ${ }^{22}$ Even on the surface, both these interpretations seem to be undermined

${ }^{15}$ For example, it was Artusi's criticism of modern concerti of instruments that led him into his more famous tirade against Monteverdi's madrigals; see Giovanni Maria Artusi, L'Artusi, overo delle imperfettioni della musica moderna (Venice, 1600), 1-13.

${ }^{16}$ For example, it was with this word that Ercole Bottrigari had praised the musicians of the court of Ferrara, to indicate their taste and judgement in combining instruments of various kinds, in contrast to his disparagement of nearly every other concerto of instruments: 'narratovi solamente il modo, colquale si procede da quei musici giudiciosi in effettuare esso gran concerto, \& laudatolo' (I simply relate the manner in which judicious musicians act to bring about this great concerto, and praise it). See Ercole Bottrigari, Il Desiderio, or Concerning the Playing Together of Various Musical Instruments, trans. Carol MacClintock (Musicological Studies and Documents, 9; Neuhausen, 1962 ), 53 (translation slightly adjusted).

${ }^{17}$ The Affetti musicali contain numerous instances in which Venetian spelling is used instead of Tuscan, a fact that may relate to the book's local origins, and perhaps even to a sense of pride in the conventions of the Venetian social practices that, as I suggest below, gave rise to the volume.

18 See Marini, Affetti musicali, ed. Piperno, pp. xvi-xxv.

19 On the implications of Venetian republicanism and the fluidity of Venetian society for music in a slightly earlier period, see Martha Feldman, City Culture and the Madrigal at Venice (Berkeley and London, 1995), 3-23.

${ }^{20}$ Monika Schmitter, "Virtuous Riches": The Bricolage of Cittadini Identities in Early-Sixteenth-Century Venice', Renaissance Quarterly, 57 (2004), 908-69. Schmitter proposes an analogy between the 'bricolage' of cittadini identities and the bricolage that many of those cittadini collected in the form of art, curiosities, scientific instruments, and so on. The implications of this suggestion for music are investigated in my forthcoming book, and in Rebecca Cypess, " "Die Natur und Kunst zu betrachten": Carlo Farina's Capriccio stravagante (1627) and the Cultures of Collecting at the Court of Saxony', Musical Quarterly, 95 (2012), 139-92.

${ }^{21}$ See Selfridge-Field, Venetian Instrumental Music, 397 and passim.

${ }^{22}$ Peter Allsop, The Italian 'Trio' Sonata: From its Origins until Corelli (Oxford, 1992), 8. 
by two of the titles in Marini's collection: first, like some other books of its day, the Affetti musicali includes music by another composer, in this case 'La Hiacintina', which is by Hiacinto Bondioli, 'uncle of the author'; ${ }^{23}$ and the collection also contains a piece that apparently bears the composer's own name, 'La Marina' ${ }^{24}$ In addition, while the notion that the family-name titles constituted dedications of a sort seems plausible, the structures of patronage implied by that notion remain unclear, and understanding of them would seem to require nuance depending on the music in question. Such complexities are, indeed, suggested by the way in which family-name titles were used by other composers in the period. For example, only a few of the pieces published in volumes by Salamone Rossi in the first two decades of the seventeenth century bear these sorts of title. Although Rossi, like Marini, must have published his works in the hope that they would be purchased, he evidently did not see such titles as essential to their commercial success. As a regular employee of the Gonzaga court at Mantua, Rossi may have had greater financial support from his patrons than Marini did, and his status as a Jew may have rendered him an outsider, without access to the kind of social network implied by Marini's publication. But his use of character-traits such as 'La gratiosa' as titles of some of his works - a practice not taken up by Marini-suggests that his titles served a different purpose. Character-trait titles were employed by Carlo Farina, another Mantuan-trained musician, who used them for his Italianate sonatas published in Dresden in the $1620 \mathrm{~s},{ }^{25}$ and they can be found in the 1617 collection of sacred concerti issued in Milan by Filippo Lomazzo, alongside a few titles clearly based on the family names of the composers themselves. ${ }^{26}$ In contrast, Innocentio Vivarino's book of motets and sonatas of 1620 includes no titles for the instrumental works at all-only the indications 'Sonata prima' to 'Sonata ottava'27 — and the same is true of the pieces in Dario Castello's two volumes of Sonate concertate in stil moderno. ${ }^{28}$

The use of family-name titles had a long history by Marini's day, ${ }^{29}$ but neither was it standard practice. In this case, Marini's regular use of such titles raises the possibility

\footnotetext{
23 The incorporation of a piece by someone other than the primary composer of the book is commonly understood to mean that this second personality played a part in bringing the volume to publication (as outlined in Dunn, 'The Instrumental Music of Biagio Marini', 13). However, I would suggest it might also constitute an attempt on the part of the second composer (or the primary composer, or the publisher of the volume, working on behalf of a colleague) at self-positioning within the landscape of 'ancient' and 'modern' music. Older composers or their colleagues sometimes sought to engage in the musical practices of the younger generation (one example is Giovanni Gabrieli's posthumous Sonate e canzoni of 1615), while other composers published music obviously in an older style long after it had gone out of date (here an example is Giovanni Battista Fontana's Sonate, also published posthumously in 1641, but exemplifying the stile moderno of the $1620 \mathrm{~s}$ ). These practices of publication remain to be explored in another study.

24 Although it is possible that the Marini (or perhaps Marino or Marina) alluded to here is someone other than the composer of this volume, the presence of such apparently eponymous works in other collections of the period (for example, Carlo Farina's 'Sonata detta la farina', from his Primo libro delle pavane gagliarde of 1626) points to a trend of autobiography, or perhaps self-portrait, through music. This notion also requires further exploration in a future study.

${ }^{25}$ On Farina's life and works, see Aurelio Bianco, 'Nach englischer und frantzösischer Art': Vie et oeuvre de Carlo Farina, avec l'édition des cinq recueils de Dresde (Turnhout, 2010).

${ }^{26}$ Filippo Lomazzo, Seconda aggiunta alli concerti raccolti dal molto reverendo Don Francesco Lucino ... novamente raccolta, et data in luce da Filippo Lomazzo (Milan, 1617).

${ }^{27}$ Innocentio Vivarino, Il primo libro de motetti ... da cantarsi a una voce. Con otto sonate per il violino ò altro simile stromento (Venice, 1620).

${ }^{28}$ Dario Castello, Sonate concertate in stil modern per sonar nel organo, overo spineta con diversi instrumenti, a 2 e 3 voci. Libro primo (Venice, 1621; facs. edn., Florence, 1979); id., Sonate concertate in stil modern per sonar nel organo overo clavicembalo con diversi instrumenti a 1.2.3. e 4 voci. Libro secondo (Venice, 1629; facs. edn., Florence, 1981 ).

29 Another volume that uses family-name titles throughout is Tarquinio Merula, Il primo libro delle canzone a quattro voci per sonare con ogni sorte de strumenti musicali (Venice, 1615). This volume also opens with a piece entitled after its dedicatee ('La Ghirardella', named for Giovanni Pietro Ghirardello [Ghirardelli]); like Marini's volume, it includes an eponymous work ('La Merula') and another entitled 'La Monteverde'.
} 
that they stemmed as much from the performance-based origins of the music as from a desire to sell books. Considered in this light, his printed text serves not only to enable the creation of new musical performances, but also to record events in the past, to preserve them for posterity and reflection among the people who took part in them, and to present a public record of them for emulation by others who bought the collection. $^{30}$ For those purchasers of Marini's book who were not directly involved in either his concerti or the publication, the emulation of the original musical events might have been of primary importance. By attempting to recreate Marini's concerti - either by playing the music themselves or by commissioning others to play for them - purchasers of the volume would have been able to approximate the social musical experience in the company of another set of listeners.

Marini's concerti and the publication of his Affetti musicali occurred during a pivotal period in the development of new theories about friendship, social interaction, and the concomitant expression of affetti in early modern cities. ${ }^{31}$ As Peter N. Miller has suggested, the model of friendship as something that existed only between two people uniquely suited and similar to one another - a model founded in Aristotle's Ethics and articulated in the late sixteenth century by Michel de Montaigne, among others ${ }^{32}$ was modified in this period by new ideas of friendship and civility that could exist among multiple participants of diverse social standings - within groups like those at the concerti in the Giunti home, indeed. ${ }^{33}$

This new model of friendship, directed more towards civil discourse and interaction than Aristotelian intimacy, is articulated most prominently in Stefano Guazzo's influential treatise La civil conversatione, first published in 1574 and quickly reprinted, translated, and disseminated throughout Europe. ${ }^{34}$ Guazzo's treatise, like so many of its day, is fashioned as a dialogue. The author relates a story in which, finding his brother seriously ill, he fetches a Doctor called Annibale, who aims to heal his patient through civil conversation. The discourse between doctor and patient lasts many days; at the beginning of the fourth and final book of the treatise, the interlocutors prepare to part ways by reflecting on the conversation they have just had:

I Think Maister Annibal, that he may be saide to have a full accompt of all things, who by knowledge doth understand them, and by good experience is assured of them: wherefore I dare boldly say, that I am alreadie certified, of the great and marvailous fruits which bud from the tree of Civile Conversation, in so much that you have not onlie disposed my understanding, to make it capable of these reasons alleaged by you, but by meanes also of your

\footnotetext{
${ }^{30}$ Mauro Calcagno has characterized publications that serve this multi-faceted purpose as existing 'in a liminal space between symbolic inscription and practical script'. See Mauro Calcagno, 'Performing the Self', Opera Quarterly, 24 (2008), 247-74 at 249.

31 On the points of overlap between friendship and patronage in the Renaissance, see Guy Fitch Lytle, 'Friendship and Patronage in Renaissance Europe', in F. W. Kent and Patricia Simons (eds.) with J. C. Eade, Patronage, Art, and Society in Renaissance Italy (Oxford and Canberra, 1987), 47-61.

${ }^{32}$ See Aristotle's Nicomachean Ethics, trans. Robert C. Bartlett and Susan D. Collins (Chicago and London, 2011), 163-87, and Michel de Montaigne, 'On Friendship', in The Complete Works of Montaigne, trans. Donald M. Frame (London and Stanford, 1958), 135-44.

${ }^{33}$ Peter N. Miller, 'Friendship and Conversation in Seventeenth-Century Venice', fournal of Modern History, 73 (2001), 1-31. Miller documents one event in Venetian history - the playing out of a friendship between two Venetians, one of high social rank and one a middling nobleman-considering it against the backdrop of Guazzo's La civil conversatione. See also id., Peiresc's Europe: Learning and Virtue in the Seventeenth Century (New Haven and London, 2000), 49-75.

${ }^{34}$ Stefano Guazzo, La civil conversatione . . . divisa in quattro libri (Brescia, 1574).
} 
sweet companie, I doe sensiblie feele all the superfluous humours (engendred by solitarinesse) consumed quite, \& spente in mee. ${ }^{35}$

The very act of conversation has convinced the speaker of its virtues. Indeed, Annibale assures his student that he need not fear losing his newly learned art of conversation, for although the two interlocutors must part ways, civil conversation may be practised with any number of partners, and the benefits of such interactions may be felt with all of them:

[I]f you have received anie harme by my companie, you would then wish to be sequestred from the companie of others: And if thereof you have taken anie little pleasure (as in deede you insinuate to have done) then will there be kindled in your heart an ardent desire, to be acquainted and converse with those kinde of men, which may yield you such consolation, that shall farre excell all mine, whatsoever: (and to tell you in one word) although you would you cannot, and if you could, you would neither eschew their fellowship, nor at anie time be cut of their companie. ${ }^{36}$

Perhaps most significantly, Guazzo is explicit about the emotional effects of civil conversation between the two interlocutors. Annibale, in assuring his student that the merit is not his alone, remarks: 'So do I perceive also, that in discoursing with you, with your gentill and loving conditions, you have bound mee to manifest the inward affection of my heart [tutto l'affetto del cuor mio], by outward signes \& tokens of good will.' ${ }^{37}$ Interaction among friends, facilitated by 'civil conversation', prompts the interlocutors to express their most intimate affetti. In Guazzo's formulation, civil conversation allows for interaction among groups of people of different social standing; the act of conversation arouses the affetti of the participants, and provides an outlet for the expression of those affetti. In this context, the concerti at the Giunti home may be seen as a manifestation, in both social and musical terms, of the principles presented in Guazzo's treatise.

The notion that music made in the company of friends could be an expression of this kind of friendship is a familiar one in the consideration of other repertories. It is commonly understood, for example, that the Italian madrigal of the sixteenth century - the singing of which could comprise a recreational pastime among circles of friends - could also embody the spirit of friendship that inspired its performances. ${ }^{38}$

\footnotetext{
35 Stefano Guazzo, The Civile Conversation of M. Stephen Guazo, Written first in Italian, divided into Foure Bookes, the First Three translated out of French by G. Pettie... And [the Fourth] now translated out of Italian into English by Barth. Young, of the middle Temple, Gent. (London, 1586), fo. $176^{\mathrm{r}}$. In the original publication the passage reads: 'O stimo Signor Annibale, che possa dire d'haver piena contezza delle cose colui, che per scienza le intende, \& per pruova se ne asicura; onde mi sarà lecito il dir francamente, ch'io sono hormai certo de i grandi, \& maravigliosi frutti, che nascono da questa civil conversatione, poscia che non solamente havete disposto il mio intelletto a farsi capace delle ragioni da voi sopra ciò assegnate, ma dalla vostra gratiosa compagnia io sento in me medesimo consumati gli humori della solitudine.' Guazzo, La civil conversatione, fo. $180^{\mathrm{r}}$.

${ }^{36}$ Guazzo, The Civile Conversation, trans. Pettie and Young, fo. $176^{\mathrm{v}}$. 'Onde se havete sentita qualche noia dalla mia conversatione, desidererete esser ristorato dalla conversatione altrui; \& se ne havete preso qualche poco di piacere, come pur m'accennate, si risvegliera nel cuor vostro un'ardente voglia di conoscere, \& pratticar quelle persone, le quali vi possono di gran lunga recar maggior consolatione di quel, ch'io habbia fatto, \& (per dirla in un fiato) quantunque voleste non potrete, \& quantunque potreste non vorrate fuggir la conversatione.' Guazzo, La civil conversatione, fo. $180^{\mathrm{v}}$.

${ }^{37}$ Guazzo, The Civile Conversation, trans. Pettie and Young, fo. $176^{\mathrm{v}}$. 'Cosi io sò, che con le vostre gentili, \& amabili maniere m'havete costretto conversando con voi a dimostrarvi fuori per gli occhi, \& per la fronte tutto l'affetto del cuor mio.' Guazzo, La civil conversatione, fo. 180․ Emphasis added.

${ }^{38}$ On the use of the 16th-c. madrigal as a record of gatherings among friends, see, for example, Iain Fenlon and James Haar, The Italian Madrigal in the Early Sixteenth Century: Sources and Interpretation (Cambridge, 1988), 75-80 and passim. Alfred Einstein's work on the madrigal provided a foundation for these interpretations of the madrigal as a
} 
Equally well documented is the shift that the madrigal underwent towards the end of the sixteenth century, from a vehicle for amateur musicians to a genre that embraced virtuosity and that required performance by professional singers. ${ }^{39}$ In this new scenario, the roles of singer and listener became increasingly distinct. Nevertheless, the professionalization of madrigal performance in the late sixteenth century did not necessarily make patrons and listeners any less involved in music. As Andrew Dell'Antonio has shown, the early moderns relied on the experience of attentive listening, and discussion of the music they heard, to arouse their affetti; and under these circumstances listening, too, could serve as a vehicle to foster and remember the sentiments of friendship. Dell'Antonio posits a practice of 'aural collecting', analogous to the pervasive practices of collection and categorization of art, curiosities, antiquities, and artefacts, in which listeners sought out musical experiences that would demonstrate and enhance their virtü. ${ }^{40}$ He writes:

Perhaps the primary means of 'collecting' and thus 'recollecting' sonic experiences was to place them in memory and find appropriate strategies to revisit the memorized events and the feelings they might have evoked, and in the process to establish categories whereby those musical experiences might be parsed and then 'displayed' through discussion with fellow virtuosi. A well-cultivated set of interpretive categories would then be useful to the virtuoso in evaluating and savoring a new musical performance/experience, and likewise in engaging with his peers in the discourse surrounding that sonic event. ${ }^{41}$

The memory of past musical experiences - gained through the process of listening, through 'aural collection' - recalled the affetti aroused by those experiences. These affetti could be re-enacted through discussion and recollection within the circle of peers who shared the same or similar experiences. Indeed, Dell'Antonio suggests that in the early seventeenth century, conversazione about music in moments of recreation constituted a new way to participate in musical activities ('to musick') without actually playing instruments or singing. ${ }^{42}$

To be sure, if any volume of instrumental music would seem to have been designed to encourage amateur performance by members of the upper classes, Marini's Affetti musicali is it. After all, the music it contains is, for the most part, not technically demanding. It omits the virtuosic passagework and violinistic tricks that appear in books like Dario Castello's two volumes of Sonate concertate in stil moderno and Marini's own Sonate, symphonie, canzoni, published in the following decade. In addition, its flexible instrumentation offers numerous possibilities for performance, increasing its accessibility to amateur groups. ${ }^{43}$ However, amateur performance of instrumental music cannot necessarily be considered the rule, and it seems likely that some members of the

social activity; see Alfred Einstein, The Italian Madrigal, trans. Alexander H. Krappe, Roger H. Sessions, and Oliver Strunk, 3 vols. (Princeton, 1971), ii. 743-61 and passim.

39 See Anthony Newcomb, The Madrigal at Ferrara, 1579-1597, 2 vols. (Princeton Studies in Music, 7; Princeton, 1980). On the role of Venetian academies in the composition and performance of madrigals, see Feldman, City Culture and the Madrigal at Venice.

${ }^{40}$ See Dell'Antonio, Listening as Spiritual Practice, 35-65.

${ }^{41}$ Ibid. 55.

42 Ibid. 5 and passim.

43 Allsop's suggestion that the Affetti musicali was published to meet the demands of a 'ready market of ... amateurs' implies that he, too, finds the music compatible with performance by its dedicatees. In addition to the two volumes of Sonate of Castello, cited above, the other volume mentioned is Biagio Marini, Sonate, symphonie, canzone, pass'emezzi, baletti, corenti, gagliarde, \& retornelli, a 1.2.3.4.5 \& 6 voci, per ogni sorte di strumenti ... . Opera VIII (Venice, [1626]; facs. edn., Florence, 2004). On the dating of Marini’s Sonate, see Cypess, " "Esprimere la voce humana”, 209 n. 41. 
Giunti circle participated in Marini's concerti by listening. Here Dell'Antonio's theoretical framework of aural collecting finds ready application. The inclusion in the publication of dedicatees who were either players in or listeners to these concerti seems to indicate that they were bound together through their collective experiences and shared affetti.

In fact, instrumental music was at times employed as a metaphor for interaction among friends. In his handbook of similes for use by orators, for example, the Dominican cleric Vincentio Ferrini compared friends to musical instruments (Amici ad instrumenti musicali'), writing: 'Just as it is with greater difficulty that three musical instruments are harmonized together, than two; so it is with greater difficulty that three friends are harmonized together in perfect friendship, than two. ${ }^{44}$ This rhetorical conceit may have been rooted in experience: as noted above, theorists frequently criticized mixed instrumental consorts in domestic concerti because they were not properly harmonized, and not sufficiently 'judicious'. It seems possible that, recognizing the diversity of the group represented in the published Affetti musicali, Marini attempted to infuse the collection with musical diversity, and with the spirit of civility manifested in the gatherings from which they emerged. This holds true even if only some of the personalities represented in the publication were actually present at the concerti: in connecting these people in his printed volume, Marini attempts to bring them into conversazione with one another. Ferrini's analogy between instrumental music and friendship seems to give more value to the combination of three friends than that of two: he implies that the more difficult harmonization is the one more worth attempting. So, too, Marini's musical works require 'judiciousness' and care; but the results of such a difficult social musical experiment may produce inspiring results.

If Marini's instrumental music was intended to stimulate the affetti of his listeners by inspiring them to engage in conversazione, there is frustratingly little evidence concerning the precise content of those conversations, and indeed, the proceedings of the concerti as a whole. Still, a close examination of Marini's compositional techniques might offer a glimpse of the conversations they sparked. 'La Foscarina' provides a point of entry for understanding Marini's intentions. The heart of this piece is the section marked tremolo con l'arco, which is among the earliest instances of a composer calling for bow tremolo $^{45}$ (see Ex. 1). ${ }^{46}$ As Stewart Carter has shown, this technique is meant to imitate the tremulant of the organ, which alters the flow of air through the organ pipes, creating a regular pulsation in the sound (and indeed, the basso partbook calls for the organist to turn on the tremulant at this point ['metti il tremolo']). As Carter

\footnotetext{
44 'Come più difficilmente s'accordano tre instrumenti di musica insieme, che duo. Così con maggior difficultà s'accordano tre amici insieme in perfetta amicitia, che duo.' Vincentio Ferrini, Primo alfabetto essemplare ... ad ogni stato di persone utile: ma à predicatori, oratori, $\mathcal{E}$ poeti necessario (Venice, 1586; first published 1583), 26. Also noteworthy is the definition of 'conserto' presented in the 1612 edition of the dictionary of the Accademia della Crusca: the term is first defined in general terms, as 'joined together, united' ('congiunto insieme, unito'), and only secondarily noted as a word used to refer to 'consonance of voices, and of the sounds of instruments' ('consonanza di voci, e di suoni di istrumenti'); Vocabolario degli Accademici della Crusca (Venice, 1612), 213.

${ }^{45}$ Earlier, Luigi Zenobi had counted the execution of tremolo effects as one of the required techniques for string players in his letter on the perfect musician. See Bonnie J. Blackburn and Edward E. Lowinsky, 'Luigi Zenobi and his Letter on the Perfect Musician', Studi musicali, 22 (1993), 61-107 at 86; repr. in Blackburn, Composition, Printing, and Performance: Studies in Renaissance Music (Ashgate, 2000), no. VII. My thanks to Bonnie Blackburn for referring me to this essay.

${ }^{46}$ Musical examples have been prepared from the facsimile of the first edition and checked against Piperno's modern edition.
} 


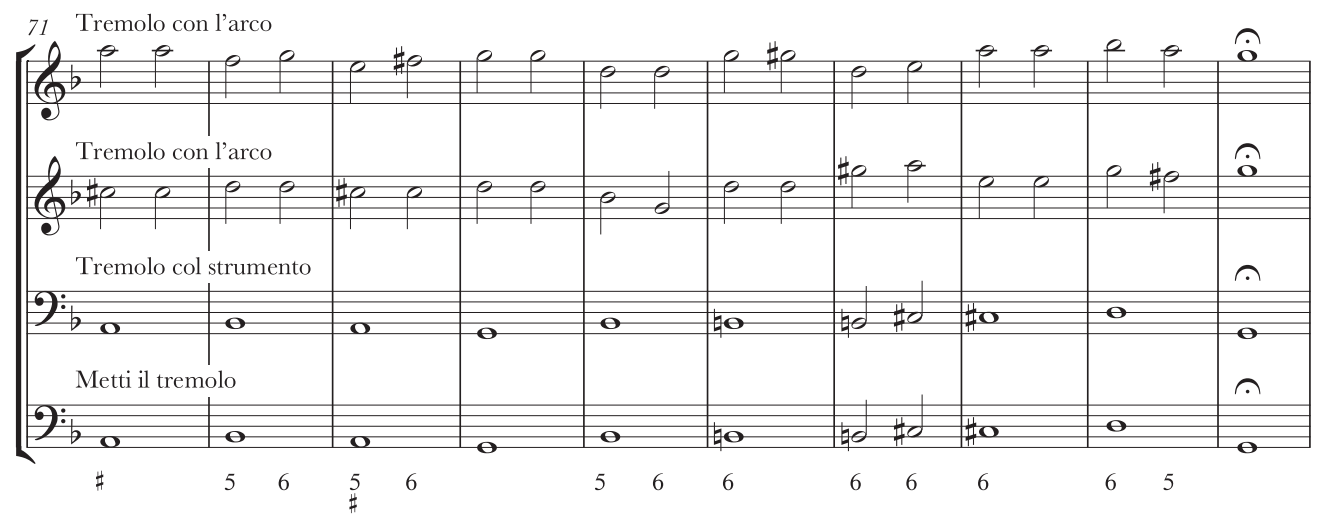

notes, the organ tremulant was associated with a melancholy affect. ${ }^{47}$ Here, however, Marini asks his violinists to arouse the same affect through the use of a new technique idiomatic to their instrument. ${ }^{48}$ I would suggest that this technique - and the mimesis involved in its execution - would have served as a focal point of conversation for Marini's listeners; it would have aroused both the affect of pathos associated with the organ tremulant, and also a sense of meraviglia - of wonder - at the capacity of the violin to imitate that instrument.

Another useful example is 'La Bemba', described in the table of contents as a canzone in ecco. The echo was, of course, a common effect in both Italian vocal and instrumental music at the turn of the seventeenth century, and, as Eric Bianchi has recently suggested, the use of echo effects in music may be linked to scientific exploration of the echo in nature. ${ }^{49}$ In 'La Bemba' Marini encourages conversazione about the echo through his use of two different types of echo effects: at bar 57 the two instruments play forte, in parallel thirds; they then repeat the same music, but piano. This pattern continues for eight bars, but at bar 65 the pattern is disrupted through the insertion of an extra half-bar repetition, marked piano (see Ex. 2). This disruption results in a moment of silence, as if the artificial music is searching for a way to continue its mimesis of the natural echo. It settles upon a completely new motif, and a new method of echoing, in which the two instruments play in canon, with the initial idea in the canto primo echoed at the unison one bar later. The humour inherent in Marini's attempts at artificial representation of a natural phenomenon is underscored in the final cadence, where the bass line drops out entirely (not shown in the example). Like the representation of the organ tremulant in 'La Foscarina', Marini's divergent representations of echo in 'La Bemba', together with his exposure of the artificiality of the musical trope, would have provided his listeners with a focal point for discourse - for conversazione, and for the experience and expression of affetti.

\footnotetext{
47 See Carter, 'The String Tremolo in the Seventeenth Century', 44 and 48.

48 The suggestion in the tavola that 'La Foscarina' may be played by 'doi violini ò corneti' is contradicted by Marini's use of the phrase 'tremolo con l'arco', apparently mandating performance on a bowed instrument.

${ }^{49}$ Eric Bianchi, 'Prodigious Sounds: Music and the World of Athanasius Kircher' (Ph.D. diss., Yale University, 2011), 157 and passim.
} 

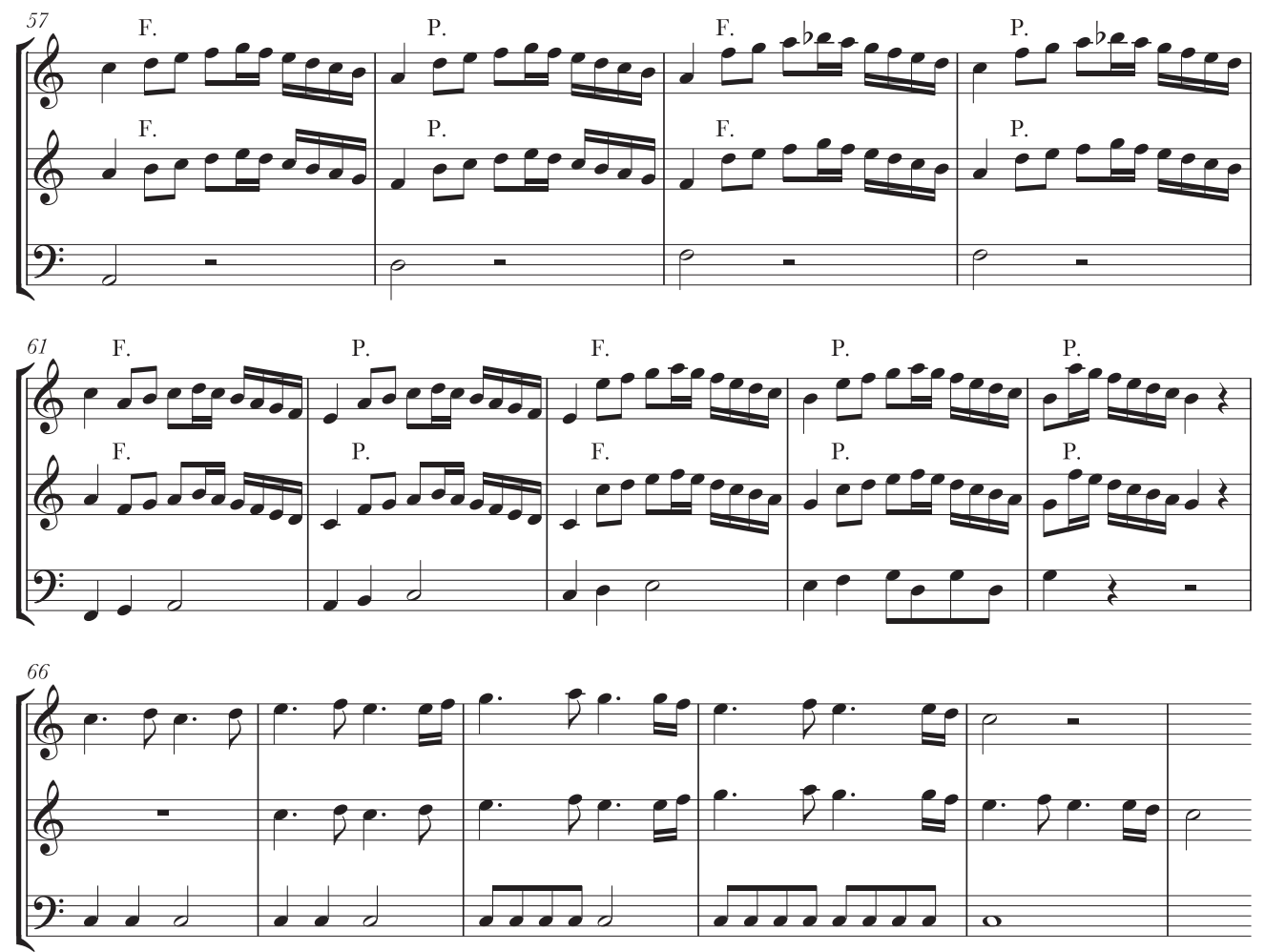

A third example is 'La Martinenga', a piece composed almost entirely of canons, although Marini juxtaposes that austere, rigid technique with an intense communication of pathos in melodic and harmonic gestures. The melodic material centres around cascading scalic figures in A minor. In the first section the canon occurs at the unison after one bar (see Ex. 3 $(a)$ ). Elsewhere, however, Marini alters it. At bar 15, for example, he intensifies the effect of the canon by quickening the imitation: here, although the melody is based on the same descending pattern, the canon occurs at the unison after only a single crotchet (see Ex. $3(b)$ ). Through the use of such affective musical gestures, an essential quality in much of the instrumental stile moderno, Marini seems to update the canon, affirming the possibility that such a formal technique may have a place in the new instrumental genres.

Like 'La Bemba', 'Il Zontino' employs echoing gestures, but here Marini indicates that the piece is composed 'ad imitation $[s i c]$ di viole grosse'. The precise meaning of this phrase is unclear. Scott Metcalfe has suggested that this imitation refers to nothing more than a brief passage in which the two canto instruments play a phrase in a high register, and then repeat the same music an octave lower; ${ }^{50}$ indeed, if Marini intended his phrase viola grossa to refer simply to a large viol, Metcalfe's suggestion would seem the only logical explanation. Nevertheless, Ian Woodfield, in a private

\footnotetext{
${ }^{50}$ Scott Metcalfe, 'Sprezzatura - alla polacca', San Francisco Bay Area Early Music News (Mar. 2003), 1 and 10-11 at 10.
} 
Ex. 3. 'La Martinenga': (a) bb. 1-5; (b) bb. 15-19

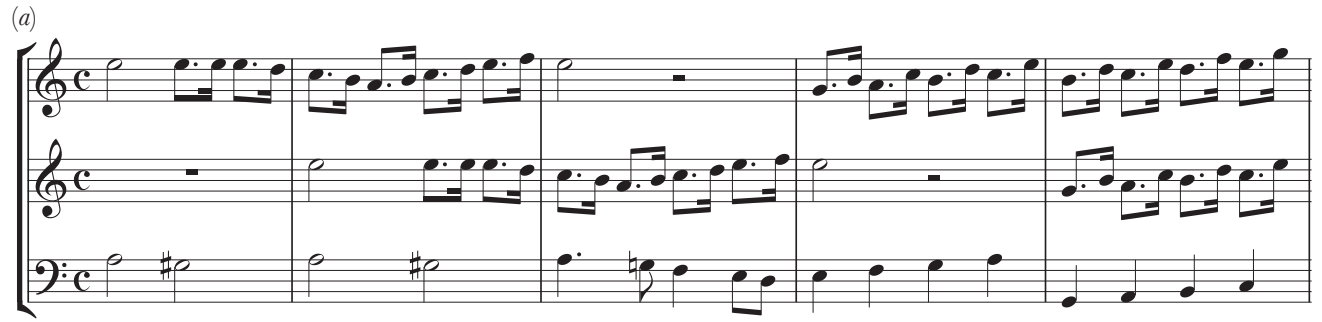

(b)
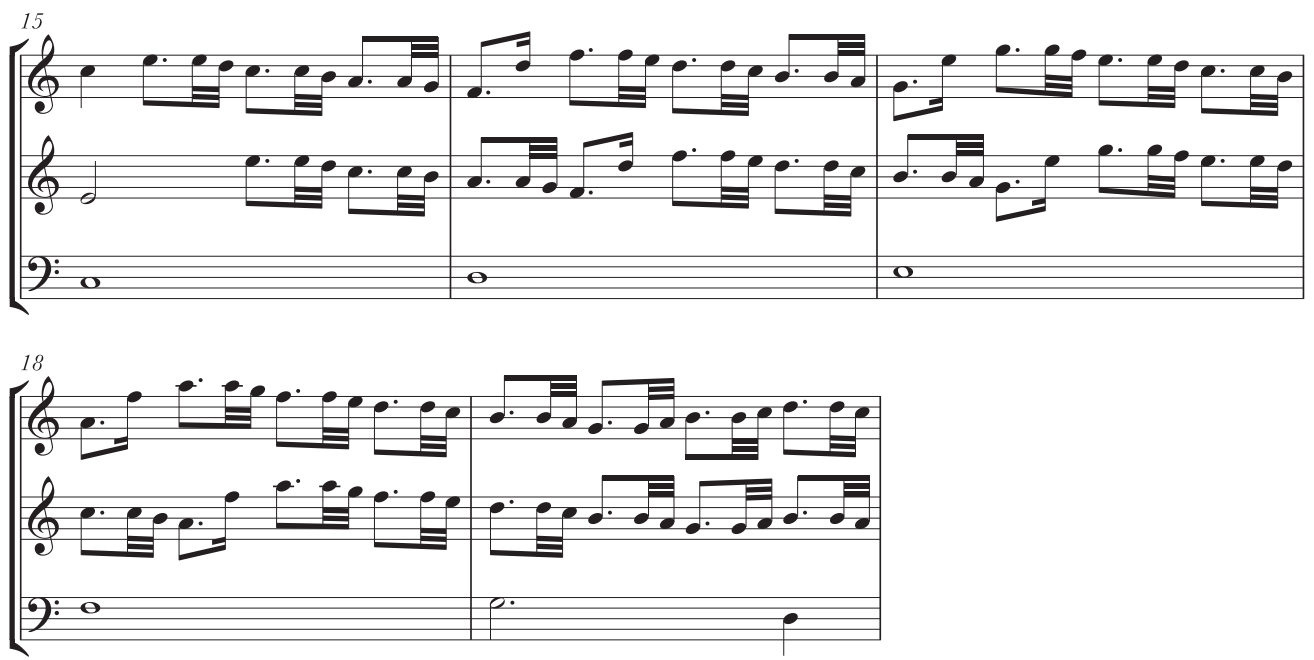

communication, has suggested an alternative interpretation: Marini may be referring here to the division techniques of the viol known in early modern Italy as viola bastarda, in which, as Jason Paras has written, the viol 'reduced a polyphonic composition to a single melodic line, derived from the original parts and spanning their ranges. Improvised counterpoints were added and the whole was decorated with elaborate diminutions. ${ }^{51}$ Although the diminutions in Marini's 'Zontino' are far less complex than most of the viola bastarda repertory, this simplification may be attributable to the fact that Marini's work is for an ensemble of instruments, in contrast to the predominantly soloistic bastarda repertory. Marini's composition presents phrases first in a simple state (see Ex. 4, bb. 1-10), and then repeated with elaborations alla bastarda (see Ex. 4, bb. 11-20). As in 'La Foscarina', 'Il Zontino' calls on the players to imitate another instrument, also applying its idiomatic performance style.

In 'La Orlandina' Marini presents another trope familiar to the early seventeenth century: the tension between composition and improvisation. The piece is capricious and quixotic, a character facilitated by its scoring: it is one of only two works in the collection composed for a single soprano instrument and continuo (the obbligato bass line essentially operates in conjunction with the chordal accompaniment), a texture that

51 Jason Paras, The Music for Viola Bastarda, ed. George Houle and Glenna Houle (Bloomington, Ind., 1986), p. xvii. My thanks to Ian Woodfield for sharing this idea with me. 
Ex. 4. 'Il Zontino', bb. 1-20

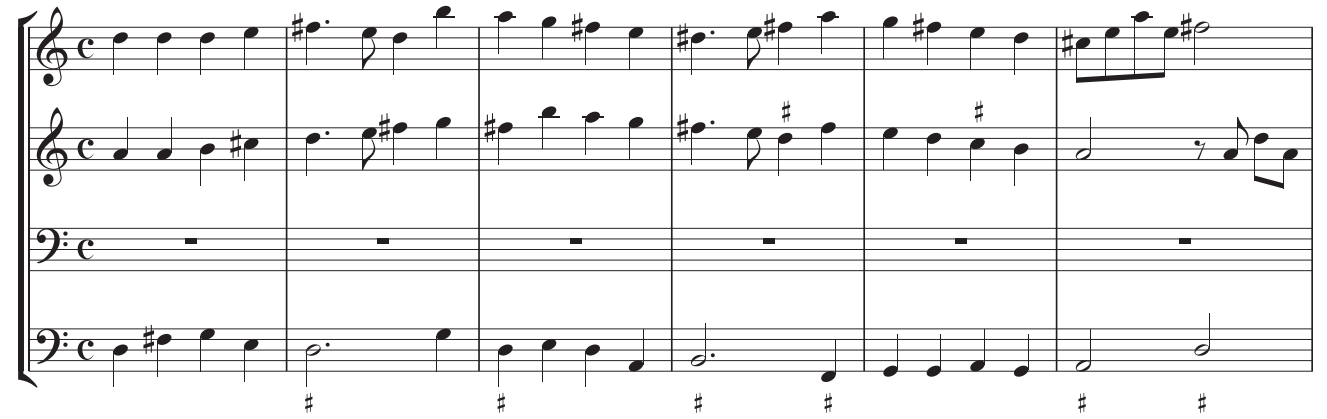

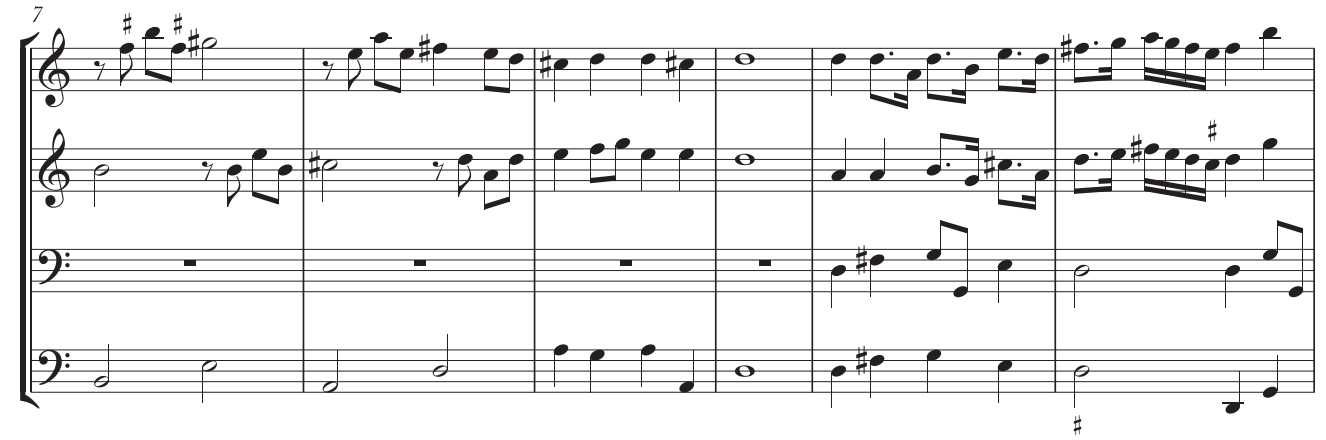
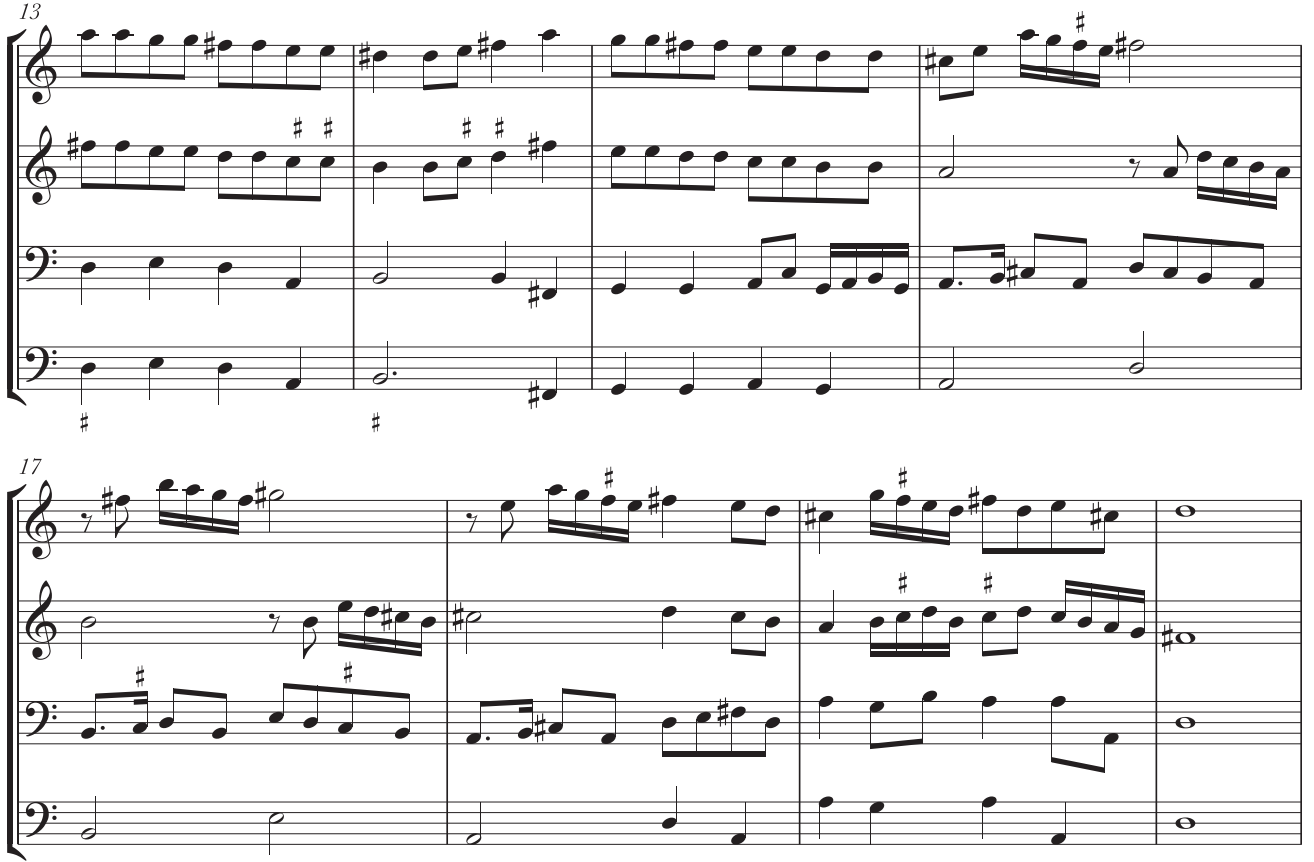
(a)

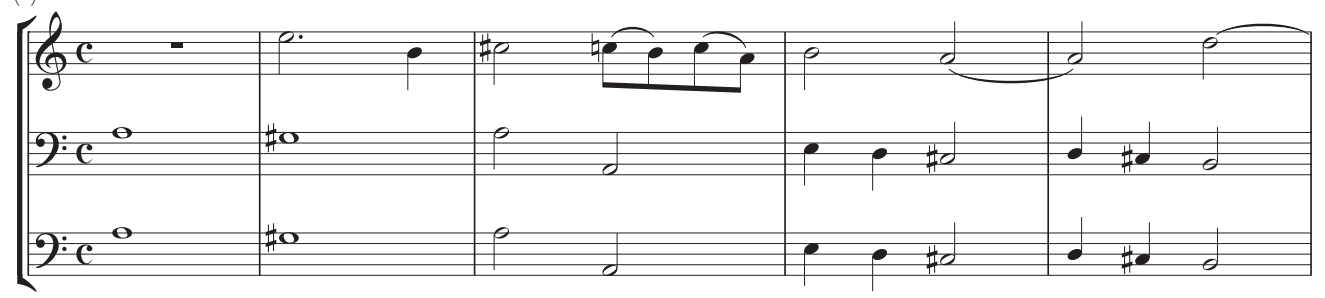

(b)

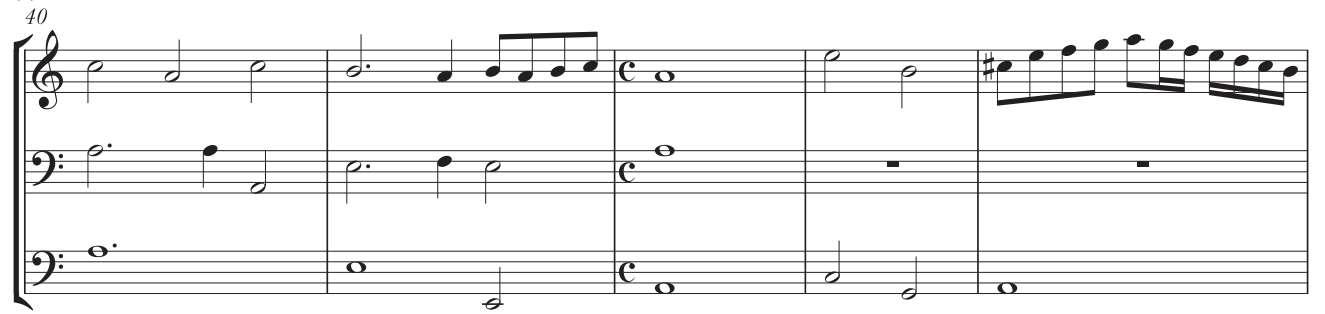

allows the soloist to assume the posture of an improviser. The piece moves easily from one idea to the next, presenting precomposed ornaments as if they occurred on the spur of the moment, and offering opportunities for metrical flexibility. And yet, a sense of planning is evident in the recapitulatory gesture at the beginning of the third section (b. 42), where the soprano instrument mimics the melody it played previously at the start of the piece (see Ex. 5); this repetition nevertheless seems to be thwarted by the whim of the player, and the final section of the piece moves in another direction. The interplay between composition and improvisation embodied in this work would have inspired a sense of wonder at the composer's virtuosity, and may also have stimulated discussion of the potential of the new instrumental style to explore the meanings and purposes of music.

'La Soranza' is one of the most curious pieces of the collection. The piece opens in duple metre; homophony gives way to simple imitation in a spirit in keeping with the folksong associations of the genre of the instrumental aria. ${ }^{52}$ The second section moves to triple metre, and the texture is simple and homophonic throughout. The third section, starting at bar 23, holds a surprise, however: here Marini provides a text, underlaid beneath the notes in each of the partbooks: 'Viva viva Cà Soranzo' (Long live the house of Soranzo) (see Pl. I). This is the only text provided for any of the music in the volume, and its function is unclear. Would the violinists have sung these words along with their instruments, repeating them throughout each of the five phrases in the third section of the piece? Were these words to be thought, but not played? Perhaps the most plausible explanation is that this tune was already associated with the words that Marini provided - that this was already a familiar song of praise or tribute, an emblem of the Cà Soranzo - and Marini was merely providing a new setting for it. One might even imagine the listeners singing along once they recognized

\footnotetext{
52 On the connections between instrumental 'arias' and folk traditions, see Luigi Rovighi, 'Violino popolare e violino barocco: Quadro dei rapporti fra due linguaggi e due prassi', in Roberto Leydi and Febo Guizzi (eds.), Strumenti musicali e tradizioni popolari in Italia (Etnomusicologia, 5; Rome, 1985), 31-55 at 44-5.
} 


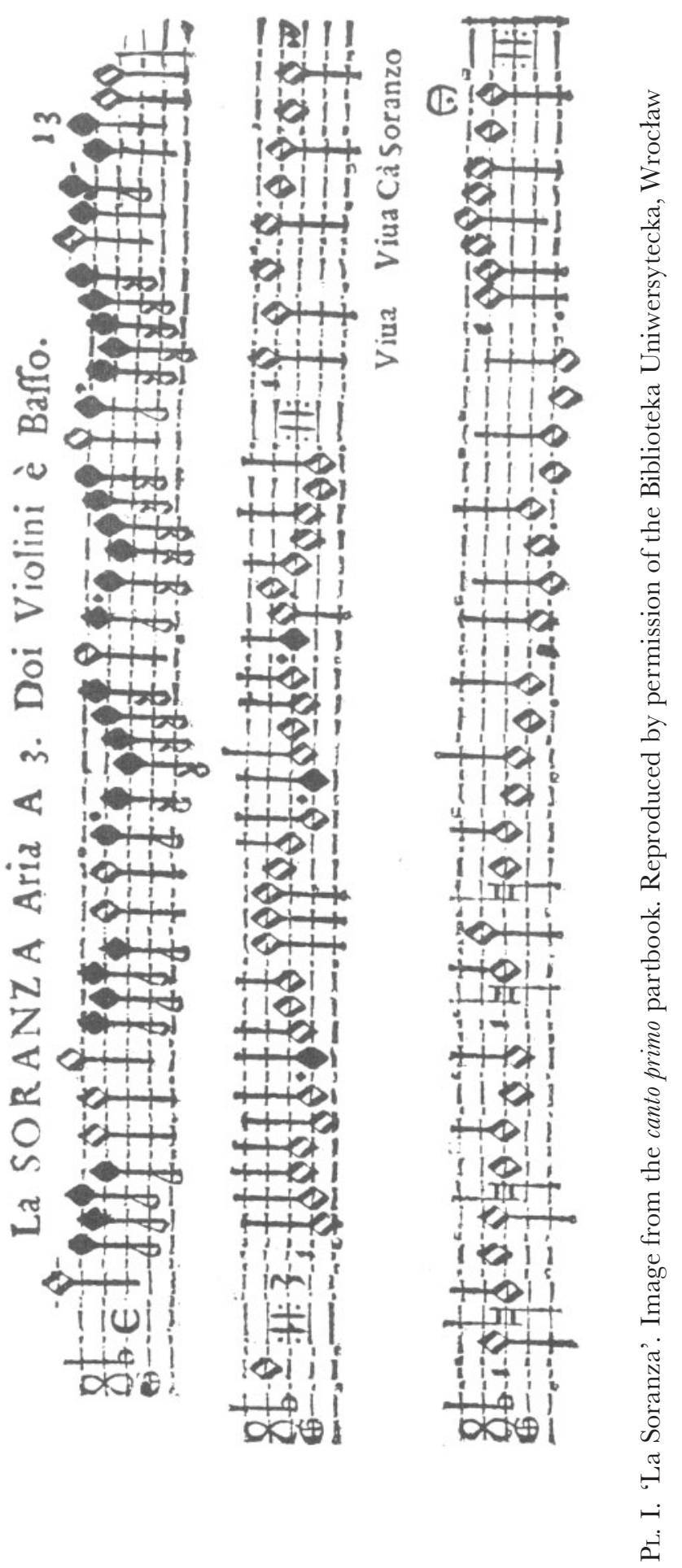



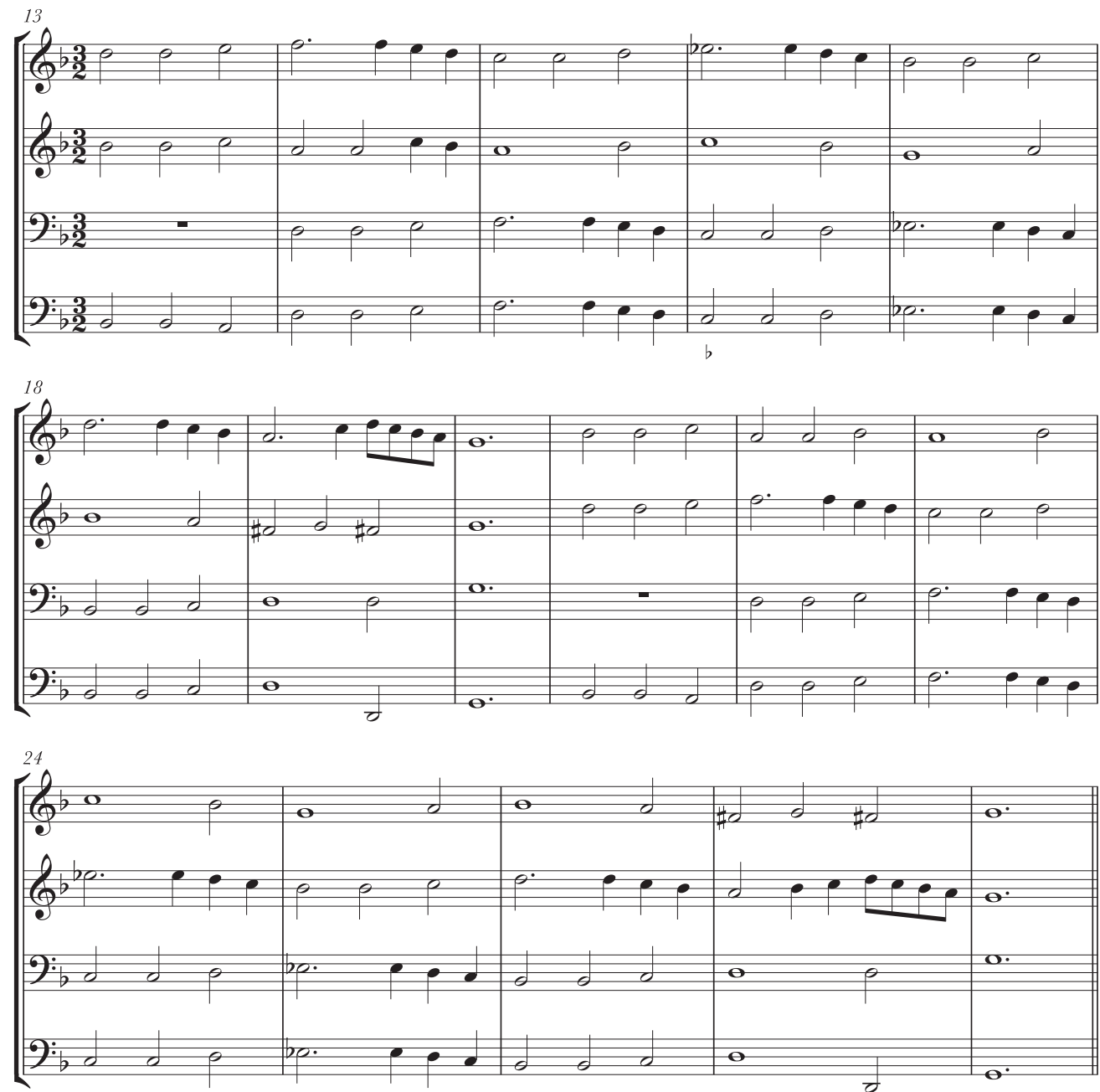

the melody. In this case, the surprise appearance of a familiar tune at the end of the work would surely have caused a stir among Marini's listeners, as they marvelled at and discussed his prowess as a composer, simultaneously renewing their affections for the person or family at the centre of his composition.

One final example is 'Il Vendramino', which stages the act of conversazione itself. The piece is constructed from short phrases, each of four or six bars, and each apparently - at least on first hearing - stated twice in exactly the same fashion. In fact this impression is illusory since Marini calls for the soprano instruments to exchange lines with one another for the repeat (see Ex. 6). It would seem natural in this context for the second iteration of each phrase to be ornamented spontaneously by these two players, who must listen to one another, learn from one another, and, in Ferrini's words, 'harmonize together in perfect friendship'. ${ }^{53}$ 
In sum, each of the works in the Affetti musicali presents its listeners with a problem or concept related to the new instrumental music. They appear to be 'test' pieces - works that probed the potential of the new style and that, in the context of the concerti in the Giunti home, were probably meant to inspire conversazione among Marini's listeners. The act of listening would have aroused a sense of meraviglia, and promoted the shared experience and expression of affetti within a diverse group of progressive listeners - of 'aural collectors'.

It is likely that, even at their premieres, Marini's works allowed for multiple interpretations, especially because, in contrast to vocal music, they lack a text to convey specific meaning. This possibility of multiple interpretations also resonates with Guazzo's ideas of civil conversation, which must by necessity be tailored to the specific needs and interests of those who participate in it, the range of available topics being nearly infinite. Having convinced his patient of the benefits of civil conversation, Annibale states, As we applie not one medicine to all griefes of the eies, so we must not use Conversation with everie one in one selfe sort. ${ }^{54}$ The patient Guazzo ultimately agrees:

Verily, I see by this time that as well for the diversitie of matters which occurre in conversation, as for the difference of the life \& manners of men, with whome we are conversant, you shal take upon you a travel \& charge farre greater than the twelve labors of Hercules, th[o]roughly to intreate of it. For considering that people differ one from another in degree, in age, in kinde, in life, in manners, \& in profession, it were a hard and tedious peece of work to set downe fully \& absolutely the proper dueties of everyone one of these, and of whoever shall frequent their companie. And I am of opinion, that when one shall have prescribed a certain fourme of conversation to all these, yet he shall not then have done, for that there must be respect had not onely to the difference which is betwene one kind \& another, but to that also which is betweene persons of one onely kind: for not onely young men differ in behavior from olde, \& Gentlemen from Women: but even young men amongst themselves differ, as also one olde man differeth in behaviour from another olde man, and one Gentleman from another Gentleman. ${ }^{55}$

To judge from Guazzo's treatise, then, topics of conversation inspired by Marini's music - especially among a group as diverse as those apparently involved in these events - may have varied widely within the group, and from one encounter to another. A single work, created, recreated, and remembered over time, might have inspired different ideas and themes of conversazione. In fact, it seems possible that this was one reason why instrumental music - by nature open to multiple interpretations - was interesting for this circle of listeners, and perhaps other similar groups equally interested in musical variety and novelty.

\footnotetext{
${ }^{54}$ Guazzo, The Civile Conversation, trans. Pettie and Young, fo. 20v. 'Come noi a tutte l'indispositioni de gli occhi non diamo un' stesso colbirio, cosi non dobbiamo converser con tutti ad un medisimo modo.' Guazzo, La civil conversatione, fo. $21^{\mathrm{V}}$.

${ }^{55}$ Guazzo, The Civile Conversation, trans. Pettie and Young, fo. $21^{\mathrm{r}-\mathrm{v}}$. 'Per certo io considero hora, che non tanto per la diversità delle cose, che occorrono nel conversare, quanto per la dissimilitudine della vita, \& de' costumi delle persone, con cui si conversa, pigliareste un'impaccio più grande delle dodici fatiche d'Hercole volendone compiutamente parlare, perche essendo gli huomini tra loro differenti di grado, d'età, di sesso, di conditione, di vita, di costumi, \& di professione, sarebbe cosa malagevole, \& di lungo tempo il proporre a pieno quel, che si convenga a ciascuno di questi, \& a chiunque con essi ha da conversare, \& credo, che quando si sarebbe data la forma a tutti questi; non per tanto sarebbe compiuta l'opera; perche non solamente si ha d'haver riguardo alla dissimilitudine, che si vede tra una spetie, \& l'altra, ma a quella, che si vede tra le persone d'una sola spetie; perche non solamente sono differenti di costumi i giovani fra loro, si come è anco differente di costumi un vecchio, da un'altro vecchio, \& un nobile, da un'altro nobile.' Guazzo, La civil conversatione, fo. $22^{\mathrm{r}-\mathrm{v}}$.
} 
Performances of Marini's music in the Giunti home were enabled by the new artifice and machinery of musical instruments. The printed volume was likewise made possible by a new technology: the printing press. Although no longer exactly 'new' at the time of these compositions, it was evidently still a source of wonder, a fact that is demonstrated by the first of three poems 'in lode dell'autore' (in praise of the author) printed at the end of the Affetti musicali. The poem is by Pietro Petracci (here rendered in the Venetian spelling, 'Petrazi'), who, by the time Marini's book appeared in print, was an accomplished poet and editor, having published numerous collections: ${ }^{56}$

\section{Pietro Petracci, 'In lode dell'autore'}

Queste note soavi, e questi accenti

Con sí mirabil arte

Vergate in queste carte

Sono de nostri cor dolci alimenti;

E mentre intento gli odo

Gioia Celeste i' godo

Ma che? Spirto divin sotto uman volto

De gli orecchi L'ambrosia hà qui raccolto.
These gentle notes, and these accents

With such marvellous arts

Written in these pages

Are sweet food for our hearts;

And while I listen intently

I delight in heavenly joy.

But what? Divine spirit beneath a human face

Has here collected ambrosia for the ears. ${ }^{57}$

Petracci's poem highlights the composer's ability to transfer live music-making to paper. The printed text - the tangible object that memorializes the music and enables its re-enactment - constitutes 'food', a source of physical sustenance. The ineffable experience of sound, by contrast, is a 'heavenly joy'. Ambrosia, the food eaten by the gods and the substance by which they become immortal, is a mediator between music in its aural manifestation and music in its representation on paper. The printed text thus confers immortality upon the sounded concerti.

Petracci's involvement in another publication issued shortly before Marini's Affetti musicali might also shed light on the composer's musical project. Volumes of letters by the abbot and poet Angelo Grillo had been published by Venetian presses as early as 1608, but in 1612 Petracci compiled and published a new collection of Grillo's correspondence, 'ordered according to their subjects [capi], with prefaces for each subject, in which is explained the artful manner of composing letters well, according to the usage of the most highly praised Latin and Tuscan authors. ${ }^{58}$ In 1616 the volume saw a fourth, expanded printing. ${ }^{59}$ These and the other volumes of Grillo's letters edited by Petracci amount to many hundreds of pages, and serve as a window onto the self-conscious stylizing of friendship through the public medium of the printed word.

\footnotetext{
56 At least one work suggests a relationship with the Venetian Giunti press, since it was published by that firm: Pietro Petracci, Ghilranda [sic] dell'Aurora, scelta di madrigali de' più famosi autori di questo secolo (Venice, 1609).

${ }^{57}$ The poem is printed in each partbook, appearing, for example, after p. 14 in the canto book. My thanks to Robert Holzer for his suggestions concerning this translation.

58 Angelo Grillo, Lettere del reverend.mo P.D. Angelo Grillo abbate di S. Benedetto di Mantova, E̊ presidente generale della congregatione cassinense. Nuovamente raccolte dal Sig. Pietro Petraci nell'Accademia de gli Sventati di Udine detto il Peregrino. E tutte dal medesimo ordinate sotto i loro capi, con le prefazioni à ciascun capo, nelle quali si dona il modo artificioso del ben compor lettere, secondo l'uso de' più pregiati autori latini, E toscani (Venice, 1612). On Grillo see Elio Durante and Anna Martellotti, Don Angelo Grillo O.S.B. alias Livio Celiano: Poeta per musica del secolo decimosesto (Florence, 1989).

59 Angelo Grillo, Delle lettere del reverend.mo Padre Abbate Angelo Grillo volume primo, in questa quarta impressione con nuova raccolta di moltaltre, fatta dal Sig. Pietro Petracci nell'Accademia de gli Sventati di Udine detto il Peregrino. Et tutte dal medesimo ordinate sotto i loro capi, \&̊ di argomenti arricchite, con le prefazioni à ciascun capo, nelle quali si dona il modo artificioso del ben compor lettere secondo l'uso de' più pregiati autori, latini, Ë toscani (Venice, 1616).
} 
Petracci extracts from Grillo's writings some basic rules for the composition of letters of various sorts and for a wide array of occasions and circumstances. Although this was certainly not the first such collection, Petracci and Grillo are perhaps especially eloquent in articulating the purposes of letter-writing for the preservation of both friendship and memory. In the following passage, for example, Petracci seems to build on Guazzo's theories of conversation as a catalyst for friendship by proposing an analogy between conversation (the temporal activity that forms and maintains friendship) and letters (a static medium that refreshes and preserves it): 'If friendship is conserved by means of conversation, as soon as distance occurs, little by little they miss each other until the final dissolution [of the friendship].... For this reason was there invented a very beautiful means of maintaining [friendship] with letters. ${ }^{60}$ Petracci then provides a structure for the composition of various sorts of letters. In his template for a letter to an equal he augments the idea of letter-writing as a means of preserving memories of 'la solita affezione' (the customary affection) shared by friends in their temporal interactions: ${ }^{61}$

Writing to our equals, the start of the letter touches generally and briefly on his sweet customs, his virtues, upon which, we say, our friendship is founded, never to be lost. In the second section, we endeavour to persuade him that fresh memory of him lives in us, and despite distance of place or length of time the love we bear him is not cooled at all, and we will always be close to him in spirit and in thought. In the third section, which is the final part of the letter, we ask him to preserve the customary affection, which we confess to feel ever more openly the more he favours us with his commands, for which we show ourselves ready to live with ambition. ${ }^{62}$

For Grillo, the composition of a letter can also be a catalyst for remembering past encounters: the receipt or revisiting of a letter can inspire memory in the reader. In a passage from a letter to Giacomo Barozzi, ${ }^{63}$ Grillo compares his correspondence to a portrait: ${ }^{64}$

I left Venice, and if I did not carry with me a part of Your Most Eminent Lordship, I carried your image in my heart. For to have a portrait of great men is no small thing. I contemplate

\footnotetext{
${ }^{60}$ Ibid. 603. 'Si come l'amicizia si conserva con la conversazione, così con la lontananza avviene, ch'à poco à poco s'en vadano mancando fino all'ultimo discioglimento. . . . Perlochè è stato ritrovato un bellissimo mezzo di mantenerle con le lettere.'

${ }^{61}$ Like Guazzo, who provides models for civil conversation among people of varying ranks, Petracci follows his formulae for letter writing between equals with others for correspondence between members of different social ranks.

${ }^{62}$ Grillo, Delle Lettere (1616), ed. Petracci, 603. 'Scrivendo à nostro eguale, nel principio della lettera si toccano in generale, e con brevità i suoi dolci costumi, le sue virtù, sopra le quali diremo, che essendo fondata la nostra amistà, non è mai per mancare. Nel secondo luogo, c'ingegneremo di persuadergli, che'n noi viva fresca la memoria di lui, e che per la distanza de' luoghi, ò per la lunghezza del tempo non si raffreddi punto l'amor, che gli portiamo, e che gli siamo sempre vicini con l'animo, e co'l pensiero. Nel terzo luogo, che sarà l'ultima parte della lettera, lo pregheremo à conservarci la solita affezione, la quale confesseremo di conoscere tanto più apertamente, quanto più spesso egli ci favorirà de' suoi comandamenti, de' quali mostreremo di vivere con ambizione.'

${ }^{63}$ Presumably this is the antiquarian Giacomo (Iacopo) Barozzi (Barocci), to whom a collection Grillo's poetry set to music by diverse composers was dedicated in 1613: Canoro pianto di Maria vergine sopra la faccia di Christo estinto, poesia del rever. P. Abbate Grillo raccolta per D. Angelico Patto Academico Giustiniano. Et posta in musica da diversi auttori (Venice, 1613). Alfred Einstein, 'Bibliography of Italian Secular Vocal Music Printed between the Years 1500-1700 by Emil Vogel, Revised and Enlarged', Notes, 2nd ser., 5 (1948), 277-308 at 307. See also 'Barozzi (Barocci), Iacopo', Dizionario biografico degli Italiani, vi (1964), <http://www.treccani.it/enciclopedia/iacopo-barozzi\%28Dizionario-Biografico $\%$ 29/> (accessed 7 July 2011).

${ }^{64}$ Based on Grillo's comparison between the effects of his letters and those of portraits, it seems plausible to consider the works in the Affetti musicali for their relationship with portraiture, and the whole volume as a portrait collection. Although such a consideration lies outside the scope of the present study, it is one that I undertake in my forthcoming book.
} 
it often, and I view it especially, as you do, in those gentle moments of recreation [otio], to lighten the weight of your heavy cares with these, my more fortunate than worthy writings. ${ }^{65}$

Just as the portrait of Barozzi that Grillo carries in his imagination can inspire memory of friendship, keeping that friendship alive, so too Barozzi can read and reread the letter from Grillo to refresh his affection for the writer.

In another passage, Grillo makes explicit the way in which letters existed outside the temporal sphere. Writing to Bartholomeo Zucchi, ${ }^{66}$ he excuses himself for his delayed response to Zucchi's earlier letter:

Upon my return from Parma ... I found a [letter] from your Lordship dated 8 March: I will not say old, for your letters are not subject to time, but I will say late, with respect to my long voyage, and my long anticipation.... In receiving it I felt a movement of spirit, in reading it happiness of heart, in rereading it notable displeasure; for in receiving one [letter], I realized I had missed two. ${ }^{67}$

Here, then, Grillo emphasizes the permanence of this letter, which is 'not subject to time', as opposed to the fleeting experience of live interaction between friends. Through the static, constant medium of the letter the reader is able to recreate some of the feelings inspired by that interaction; indeed, Grillo and Petracci use the word amicizia hundreds of times in characterizing the purposes and meanings of the letters.

In one particularly expressive passage, Grillo highlights the potential of letters to carry affetti between friends:

Letters now cry, now laugh, now weep, now play, now accuse, now excuse, now become enraged, now are pacified, now chat, now describe, now teach, now labour, now praise, now blame, now woo: in sum they are nothing but the living images of our spirits, the language of our thoughts, the personal speech of our affetti. ${ }^{68}$

To summarize, for Petracci and Grillo the letter is a means of persuading the reader of the writer's friendship and of reviving the spirit of friendship between both reader and writer; it is a portrait of the writer; a permanent object; and a capsule that contains the spirits, thoughts, and affetti of the correspondents, bringing them to life, paradoxically, through the static medium of the printed word. The written text is a permanent object that enables the temporal experience of friendship; in this case, the

${ }^{65}$ Grillo, Delle Lettere (1616), ed. Petracci, 897. 'Partij di Venetia: \& se non portai meco parte di Vostra Signoria Clarissima, ne portai però nel cuore l'imagine. Che de grandi huomini non è poco havere il ritratto. In questo contemplola spesse volte, \& veggiola spetialmente, quasi in gentile otio allegierir talhora il peso delle sue grave cure in que' miei più fortunate, che meritevole scritti.'

${ }^{66}$ Zucchi was a collector of letters himself, as can be seen from his three-volume Scelta di lettere di diversi eccellentiss. scrittori, disposta da Bartolomeo Zucchi da Monza (Venice, 1595). He later expanded this collection, combining it with his treatise in L'idea del segretario ... rappresentata in un trattato de l'imitatione, e ne le lettere di principi e d'altre signori (Venice, 1600). Correspondence from Grillo is included in these collections.

${ }^{67}$ Grillo, Delle Lettere (1616), ed. Petracci, 787. 'Nel mio ritorno di Parma . . hò trovato una di Vostra Signoria di 8. di Marzo: non dirò vecchia, perche le sue lettere non sono soggette al tempo; ma dirò tarda, rispetto al mio lungo viaggio, \& alla mia lunga espettatione.... Hor nel riceverla hò sentito moto di animo, nel leggerla allegrezza di cuore, nel rileggerla dispiacer di momento; perche mentre ne ricevo una, m'aviso, ch'io n'hò perduto due.' Emphasis mine.

${ }^{68}$ Grillo, Delle Lettere (1616), ed. Petracci, 504. 'Le lettere hora piangono, hora ridono, hora si dolgono, hora scherzano, hora accusano, hora scusano, hora s'adirano, hora si placono, hora discorrono, hora discriveno, hora insegnano, hora effortano, hora lodano, hora biasimano, hora corteggiano: \& in soma altro non sono, che vive imagini dell'animo nostro, lingua de' nostri pensieri, \& favella domestica de' nostri affetti.' Emphasis mine. 
printed text takes on the additional dimension of being a public testimony to that friendship, and a public model for its replication among readers.

The suggestion of a connection between Marini's music with the work of Grillo and Petracci is not haphazard. There is a strong likelihood that Marini knew Grillo. He certainly knew some of Grillo's work: he set one of Grillo's texts in his Madrigali $e$ symfonie, Op. 2, published just a few months after the Affetti musicali, ${ }^{69}$ and the instrumental portion of that volume includes a symfonia entitled 'La Grilla', which may refer to the same author. ${ }^{70}$ Included in the Madrigali e symfonie, too, is a setting of a poem by Petracci, which, combined with Petracci's contribution of a dedicatory poem to the Affetti musicali, suggests that Marini and Petracci also travelled or worked in the same social circles in Venice. ${ }^{71}$

And indeed, aspects of Marini's publication resonate with the themes and concerns of Grillo's letters. Even if the family-name titles of the works in Marini's Affetti musicali had a commercial function, they also bear similarities with the printed letters of Grillo. The 'judicious concerti of your recreations' to which Marini refers in his dedication may be seen as analogous to the moments of otio in which friends may revisit letters from each other, reviving the affects that accompany their friendship. Marini's concerti in the Giunti home, which included performances of at least some of the pieces in the printed collection, might well be considered an expression of friendship among the closed circle of attendees. This notion is amplified by the title Affetti musicali: it is friends, Grillo says, who use letters to share the 'living images of our spirits, the language of our thoughts, the personal speech of our affetti ${ }^{72}$

To be sure, the listeners at the Giunti home must have been an invited group, but their willingness to participate in such a diverse gathering reflects the republican pretensions of the Venetian class of cittadini. As Piperno notes, this class of Venetian society was associated with novelty in artistic and intellectual trends:

The progressive political 'coloring' of the dedicatees of Marini's works ... certainly tells us that his professional figure and his artworks were especially dear to the emergent and innovative strata of the complex social framework of the Serenissima. The consumers and patrons, ideologic-

\footnotetext{
69 Biagio Marini, Madrigali e symfonie (Venice, 1618). Selections from the collection are presented in modern edition with an introduction in id., Madrigali e Symfonie, Op. 2, ed. Thomas D. Dunn (2nd edn., Web Library of Seventeenth-Century Music, 3; 2005), <www.sscm.wlscm.org >. As already noted, the true publication date of the Affetti musicali according to the modern calendar may have been 1618 as well. In addition to this text, Marini set another by Grillo: 'Care lagrime mie', in his Madrigaletti ...con alcune Villanelle (1635). My thanks to Bonnie Blackburn for providing this reference.

${ }^{70}$ Selfridge-Field assumes that 'La Grilla' is in fact dedicated to the composer Giovanni Battista Grillo; as far as I know this cannot be proven definitively. It may be a mere coincidence that Grillo's poem appears at the eighth madrigal in the vocal portion of Marini's Madrigali e symfonie and that 'La Grilla' is the eighth work in the instrumental portion, but it also seems possible that Marini meant to connect the two pieces through this parallel positioning. See Selfridge-Field, Venetian Instrumental Music, 129.

${ }^{71}$ In his primary post, Marini worked as a musico at San Marco under the supervision of Monteverdi, whose correspondence with Grillo is well known. Monteverdi himself received one of the dedications in the Affetti musicali. The two poets and the two composers probably crossed paths in some way at some point during this period; although this point cannot be proven definitively, it is tempting to speculate that they all attended or participated in the concerti at which Marini's music was featured. On the Grillo-Monteverdi correspondence, see Denis Stevens, Monteverdi in Venice (Madison and London, 2001), 56-7. Monteverdi is represented in Marini's collection by a 'baletto alemano'; the use of a 'German' genre may be noteworthy, since, as a Mantuan subject, Monteverdi's ultimate loyalty was to the Habsburg court. His loyalty to Venice was apparently called into question in an undated and anonymous document presented to the Venetian State Inquisitors; see Jonathan Glixon, 'Was Monteverdi a Traitor?', Music \& Letters, 72 (1991), 404-6.

${ }^{72}$ See n. 68 above.
} 
Ex. 7. 'La Foscarina', bb. 1-4

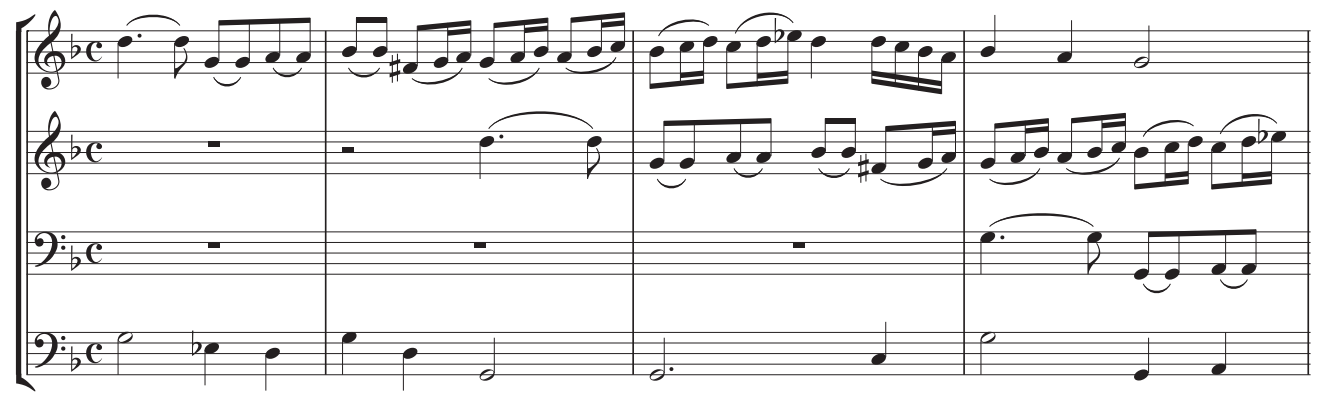

ally oriented towards new and modern things, certainly did not hesitate further to express their tendencies by appreciating and soliciting the novelty of Marini's musical creations. ${ }^{73}$

Piperno hesitates to ascribe this 'progressive' collection of personalities within the Affetti musicali to a 'conscious and premeditated choice on the composer's part'. Indeed, as I have suggested, consideration of the book as a product of musical events in the Giunti home implies that the composer's choice may not have been the issue: Marini's dedicatees may have received this honour at least in part because they were present at those events. Equally, progressive purchasers of Marini's printed text-like those who bought volumes of printed letters - gained a window onto these gatherings. Whether they played the music in that volume themselves, or heard it played by others, buying the book allowed them a taste of the stylized affetti inscribed in Marini's music.

Beyond this general connection between the work of Marini and the published letters of Grillo and Petracci-a link that operates on the level of function and social usage - a close reading of Marini's music suggests that on a compositional level, too, he may have been interested in finding ways to stay the passage of time - to capture his concerti for posterity, creating a fixed portrait of his listeners, and of their conversazione and affetti. Throughout the Affetti musicali, Marini uses musical techniques that project a sense of stasis or circularity, a sense that his music, like Grillo's letters, is 'not subject to time'. I believe that these techniques present a tension between the teleological, linear movement inherent in the temporal medium of music and the desire of Marini and his listeners to preserve the affetti of their friendship - and their music - on paper.

In keeping with this interest in memory, I propose to revisit the music examples examined previously. The centrepiece of 'La Foscarina' is the section imitating the organ tremulant shown in Ex. 1 above. But the tremolo effect - with its associations of pathos - was in fact foreshadowed at the opening of the piece by the use of slurred bowings (see Ex. 7). Thus the tremolo passage itself brings the listener back to the music heard at the start of the piece. It may be the memory of that opening moment - and its loss to the passage of time - that inspires feelings of melancholy, of sadness, in the tremolo section. Indeed, this tendency to revisit the past is enacted fully just after the tremolo section, where Marini presents a nearly literal recapitulation of the opening.

In 'La Bemba', the conceit of the piece is the echo effect, which by definition involves the capture and replication of music heard in the past. Especially in the section in

${ }^{73}$ Marini, Affetti musicali, ed. Piperno, p. xv; translated in Dell'Antonio, Syntax, Form, and Genre, 273. 
which the two instruments play in canon, and thus have overlapping statements of the same material (see Ex. 2 above, starting at b. 66 and continuing beyond the end of the example), the listener is presented with a sort of musical double vision, in which the momentary sound is frozen, copied, and heard again. This effect is intensified in the increasingly close kaleidoscopic canons of 'La Martinenga' (Ex. 3 above): particularly in Ex. 3(b) and similar passages elsewhere in the piece, the listener is presented with a problematized understanding of time, in which cascading, overlapping scales over a slow-moving bass line appear simultaneously to still the harmonic motion and also to increase the urgency of the melodic repetition.

In both 'Il Zontino' and 'Il Vendramino', the focus of the composition as a whole is on the repetition of sounds previously heard. In the former (Ex. 4 above) Marini uses his printed volume to instruct the performers in the bastarda techniques of variation; in the latter (Ex. 6 above) he leaves the process of elaboration (or its omission) up to the performers, but draws attention to the ability of each of the two canto instrumentalists to collaborate in recalling and reproducing each other's sounds. And, as has already been noted, the soloist in 'La Orlandina' poses as an improviser, apparently mining his memory of the music already made in order to produce new material in the third section of the piece (Ex. 5 above). Thus even in a work that probes the boundary between composition and improvisation, the soloist cannot escape the need to preserve and revive memories of the music already lost to time.

Finally, let us return to 'La Soranza'. I suggested earlier that the text provided by Marini in the third section of the work could indicate a connection to a pre-existent tune - one that Marini's listeners and purchasers of his book might already have associated with the Soranzo family. In this case, the tune itself would constitute a sort of musical object: an emblem of the dedicatee. In a live, sounded performance of 'La Soranza' the tune lasts only a short time, but as an object - a kind of ossified musical symbol - the Soranza melody endures through time as a permanent tribute.

In all these examples, and in many others as well, Marini creates the effect of an ongoing engagement with musical memory by means of devices that project a sense of constancy or circularity - of permanence in the face of temporary sound. I suggest that the composer brings all these devices and techniques together in a single collection to defy the temporal nature of both conversation and music, and to preserve fleeting experiences for posterity. In its sounded manifestation the music allows listeners to contemplate an idea repeatedly, considering the affetti it encapsulates or stimulates over an extended period of time, perhaps like a musical portrait, static and constant. ${ }^{74}$ In its printed form, the music, with its techniques of circularity, allows for the recollection of those moments of affective contemplation.

The title of Marini's volume alludes to the composer's attempt to record musical affetti on paper - to preserve them as a letter would preserve the emotions shared by friends. Although Marini left no explicit indication of his ideas in composing and publishing the Affetti musicali, I propose that the revolution in instrumental music to which Marini contributed found some of its inspiration in the new ideals of friendship

\footnotetext{
74 The notion that circularity in musical form may present a sense of stasis - in fact, a 'portrait' of the musical subject - has been fruitfully explored with regard to the 'character pieces' of early 18th-c. France (especially those of François Couperin) and the pieces based on that model by Carl Philipp Emanuel Bach, composed mostly in the 1750s. See e.g. Darrell M. Berg, 'C. P. E. Bach's Character Pieces and his Friendship Circle', in Stephen L. Clark (ed.), C. P. E. Bach Studies (Oxford, 1988), 1-32. Indeed, there are numerous points of overlap between the works in the Affetti musicali and other volumes of its day and these later repertories; these intersections have received virtually no attention in the scholarly literature thus far.
} 
expressed by Guazzo, Grillo, and Petracci-ideals that were perhaps especially at home in republican Venice. By manipulating the passage of time, and problematizing a purely linear conception of music, Marini offered participants in his concerti the possibility of preserving their past civil conversations, inspired and aided by his music. Using the artificial machinery of musical instruments, and compositional techniques that display his own virtuosity in the use of musical artifice, Marini sought, as Galileo suggested, to 'awaken the secret affetti of our soul'.

\begin{abstract}
In entitling his debut publication of 1617 Affetti musicali, Biagio Marini became the first composer to use the suggestive term affetti in the title of a book consisting entirely of instrumental music. Marini indicated that the book grew out of live music-making among a progressive group of Venetian listeners. Consideration of these social musical events in the context of early modern theories of friendship and civilityespecially those articulated in Stefano Guazzo's Civil conversazione (1574)-sheds light on Marini's project. His compositions may have been intended as 'test' pieces, meant to inspire conversation among his listeners, thereby arousing their affetti. In its published form, the Affetti musicali constitutes a record of those discussions and the affetti they inspired, as well as a public model for emulation by other like-minded listeners.
\end{abstract}

